\title{
OH reactivity and concentrations of biogenic volatile organic compounds in a Mediterranean forest of downy oak trees
}

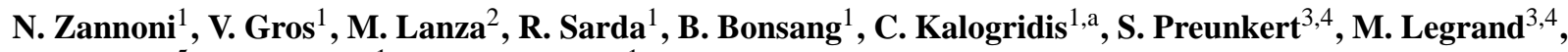 \\ C. Jambert ${ }^{5}$, C. Boissard ${ }^{1}$, and J. Lathiere ${ }^{1}$ \\ ${ }^{1}$ LSCE, Laboratoire des Sciences du Climat et de l'Environnement, CNRS-CEA-UVSQ, Orme des Merisiers, \\ 91191 Gif sur Yvette, France \\ ${ }^{2}$ Ionicon Analytik GmbH, Eduard-Bodem-Gasse 3, 6020 Innsbruck, Austria \\ ${ }^{3}$ CNRS, Laboratoire de Glaciologie et Géophysique de l'Environnement (LGGE), 38000 Grenoble, France \\ ${ }^{4}$ Univ. Grenoble Alpes, LGGE, 38000 Grenoble, France \\ ${ }^{5}$ Laboratoire d'Aerologie, Université de Toulouse-CNRS, 14 Avenue Edouard Belin, 31400 Toulouse, France \\ ${ }^{a}$ now at: Institute of Nuclear Technology and Radiation Protection, Environmental Radioactivity \\ Laboratory, National Centre of Scientific Research "Demokritos”, 15310 Ag. Paraskevi, Attiki, Greece
}

Correspondence to: N. Zannoni (nora.zannoni@1sce.ipsl.fr)

Received: 12 June 2015 - Published in Atmos. Chem. Phys. Discuss.: 17 August 2015

Revised: 13 January 2016 - Accepted: 26 January 2016 - Published: 11 February 2016

\begin{abstract}
Total $\mathrm{OH}$ reactivity, defined as the total loss frequency of the hydroxyl radical in the atmosphere, has proved to be an excellent tool to identify the total loading of reactive species in ambient air. High levels of unknown reactivity were found in several forests worldwide and were often higher than at urban sites.

Our study presents atmospheric mixing ratios of biogenic compounds and total $\mathrm{OH}$ reactivity measured during late spring 2014 at the forest of downy oak trees of the Observatoire de Haute Provence (OHP), France. Air masses were sampled at two heights: $2 \mathrm{~m}$, i.e., inside the canopy, and $10 \mathrm{~m}$, i.e., above the canopy, where the mean canopy height is $5 \mathrm{~m}$.

We found that the $\mathrm{OH}$ reactivity at the site mainly depended on the main primary biogenic species emitted by the forest, which was isoprene and to a lesser extent by its degradation products and long-lived atmospheric compounds (up to $26 \%$ during daytime). During daytime, no significant missing $\mathrm{OH}$ reactivity was reported at the site, either inside or above the canopy. However, during two nights we determined a missing fraction of $\mathrm{OH}$ reactivity up to $50 \%$, possibly due to unmeasured oxidation products. We confirmed that no significant oxidation of the primary species occurred within the canopy; primary compounds emitted by the forest were fast transported to the atmosphere. Finally, the $\mathrm{OH}$ reactivity at this site was maximum $69 \mathrm{~s}^{-1}$, which is a high
\end{abstract}

value for a forest characterized by a temperate climate. $\mathrm{Ob}$ servations in various and diverse forests in the Mediterranean region are therefore needed to better constrain the impact of reactive gases over this area.

\section{Introduction}

The atmospheric oxidation of volatile organic compounds directly impacts the quality of air and Earth's climate. Biogenic volatile organic compounds (BVOCs) are globally the most abundant class of reactive organic compounds in the troposphere. On a regional scale, such as in urban environments, organic compounds emitted by anthropogenic sources may dominate the atmospheric reactivity.

The dominant source of BVOCs is the foliage of terrestrial vegetation (Steiner and Goldstein, 2007); above all, trees provide the largest portion of emitted BVOCs $(75 \%$, Wiedinmyer et al., 2004), followed by shrubs and grasslands and minor sources such as oceans and soils (Bonsang et al., 1992; Guenther et al., 1995; Schade and Goldstein, 2001; Williams et al., 2004). Biogenic VOCs include isoprenoids (isoprene, monoterpenes, sesquiterpenes, etc.), alkanes, alkenes, alcohols, carbonyls, esters, ethers and acids (Kesselmeier and Staudt, 1999). Among the biogenic compounds, isoprene 
and monoterpenes are the most studied, with a number of publications covering their synthesis and emission factors (Laothawornkitkul et al., 2009), canopy fluxes (Rinne et al., 2002; Karl et al., 2007), atmospheric mixing ratios (de Gouw and Warneke, 2007; Yáñez-Serrano et al., 2015) and atmospheric role (Atkinson and Arey, 1998; Fuentes et al., 2000; Whalley et al., 2014) currently available.

Isoprene alone represents half of all biogenic compounds emitted and constitutes the largest single source of VOCs in the atmosphere, with a current global estimate of about $500 \mathrm{TgC} \mathrm{yr}^{-1}$ (Guenther et al., 2006) and large uncertainties still associated (Sindelarova et al., 2014).

When isoprene is released into the atmosphere, it is rapidly oxidized by the hydroxyl radical $(\mathrm{OH})$, ozone $\left(\mathrm{O}_{3}\right)$, the nitrate radical $\left(\mathrm{NO}_{3}\right)$ during nighttime and occasionally chlorine atoms. The presence, position and number of double bonds determine its high reactivity as a molecule. Atkinson and Arey (2003) have estimated lifetimes for isoprene ranging from a few hours with $\mathrm{OH}$ and $\mathrm{NO}_{3}$ to a few days with $\mathrm{O}_{3}$, while monoterpenes and sesquiterpenes lifetimes can range from a few minutes to hours with $\mathrm{OH}$, $\mathrm{NO}_{3}$ and $\mathrm{O}_{3}$ (with mean concentrations of oxidants equal to $2 \times 10^{6}$ molecules $\mathrm{cm}^{-3}$ for $\mathrm{OH}, 7 \times 10^{11}$ molecules $\mathrm{cm}^{-3}$ for ozone and $2.5 \times 10^{8}$ molecules $\mathrm{cm}^{-3}$ for $\mathrm{NO}_{3}$ ). By comparison, anthropogenic emitted molecules have lifetimes that vary from hours to years (Atkinson, 2000), resulting in biogenic compounds playing a dominant role in the lower troposphere and atmospheric boundary layer.

The dominant loss of isoprene is the oxidation reaction with the $\mathrm{OH}$ radical, which involves the formation of six isomeric peroxy radicals that further react in unpolluted environments, forming methyl vinyl ketone (MVK), methacrolein (MACR) and formaldehyde ( $\mathrm{HCHO}$ ) as primary products in the highest yields (Jenkin et al., 1998). Other product intermediates and secondary products in its oxidation pathway include hydroperoxides, hydroxyacetone, glyoxal, methylglyoxal, 3-methylfuran, acetic acid, glycolaldehyde and formic acid. Reactions with $\mathrm{OH}$ finally lead to the production of carbon dioxide and water, including the formation of ozone and low volatile products which can partition to the particle phase. Significant production of groundlevel ozone on the regional scale was reported by Hirsch et al. (1996) and in northeastern USA and Europe by Tsigaridis and Kanakidou (2002), while production of secondary organic aerosols was demonstrated by Claeys et al. (2004).

Furthermore, isoprene and BVOCs emissions influence the oxidative capacity of the atmosphere, impacting the lifetime of many species including long-lived species such as methane and hydrofluorocarbons, which are commonly depleted by $\mathrm{OH}$.

Total $\mathrm{OH}$ reactivity is defined as the total loss of the hydroxyl radical due to the reaction with ambient reactive molecules. It has been demonstrated to be an excellent tool for providing indirect evidence of the importance of reactive molecules in ambient air. In addition, when $\mathrm{OH}$ reac- tivity is measured together with the concentration of trace compounds, it is possible to evaluate whether all the reactive components in the studied environment are identified or not. Missing reactivity, which is the fraction of measured $\mathrm{OH}$ reactivity not explained by complementary gas phase measurements, has been already reported in several forested sites (di Carlo et al., 2004; Sinha et al., 2010; Nölscher et al., 2013). It was found to be up to almost $90 \%$ (Nölscher et al., 2012a) and usually higher than most of the urban sites investigated (Ren, 2003; Yoshino et al., 2006). Di Carlo and coworkers were the first to report evidences of a missing biogenic source in a forest in Michigan, probably associated with terpene-like emissions and not accounted for in trace gas analysis. Their work pioneered and motivated followup studies of $\mathrm{OH}$ reactivity at other forested sites, including boreal forests (Sinha et al., 2010; Nölscher et al., 2012a; Mogensen et al., 2011), temperate mixed forests (Ren et al., 2006; Mao et al., 2012; Nölscher et al., 2013; Hansen et al., 2014 and Nakashima et al., 2014) and tropical forests (Sinha et al., 2008; Ingham et al., 2009 and Edwards et al., 2013).

The Mediterranean alone emits about $40 \mathrm{t} \mathrm{km}^{-2} \mathrm{yr}^{-1}$ of BVOCs (as country-specific emission density considered for Portugal, Cyprus, Spain, Greece, Albania, Slovenia, Italy, Croatia and Bosnia/Herzegovina; Rainer Steinbrecher, 2009); its warm temperature and sunny conditions trigger emissions of BVOCs, which have a clear light and temperature dependence. Global warming is expected to impact the Mediterranean more than other areas in the world (Mellouki and Ravishankara, 2007). Model predictions have shown that this area will be characterized by higher temperatures, extended drought periods, enhanced ozone and particles levels (Giorgi, 2006; Giorgi and Lionello, 2008; Giorgi et al., 2011) all which will influence BVOCs emissions in strength and pattern (Laothawornkitkul et al., 2009). Such findings highlight the importance of conducting more intense and longterm field studies in the Mediterranean region.

Our study represents the first and only study to date of $\mathrm{OH}$ reactivity in a Mediterranean forest. It shows results of total $\mathrm{OH}$ reactivity and $\mathrm{BVOCs}$ concentration from a field experiment conducted at two heights in the forest of the Observatoire de Haute Provence (OHP), France, during late spring 2014.

The site at OHP is a special forest in the Mediterranean basin, located in the southeast of France, poorly influenced by anthropogenic pollution and known for being almost homogeneous in BVOCs emissions. The dominant tree species at the site is the downy oak (Quercus pubescens Willd.), which has been demonstrated to emit nearly exclusively isoprene in large quantities (Kesselmeier et al., 1998; GenardZielinski et al., 2015). Recent studies at OHP have shown evidence of large tree-specific intra-variability in emission strength (Genard-Zielinski et al., 2015), strong isoprene fluxes to the atmosphere (up $10.1 \mathrm{mg} \mathrm{m}^{-2} \mathrm{~h}^{-1}$ ) during summer 2010 (Baghi et al., 2012) and up to $9.7 \mathrm{mg} \mathrm{m}^{-2} \mathrm{~h}^{-1}$ dur- 


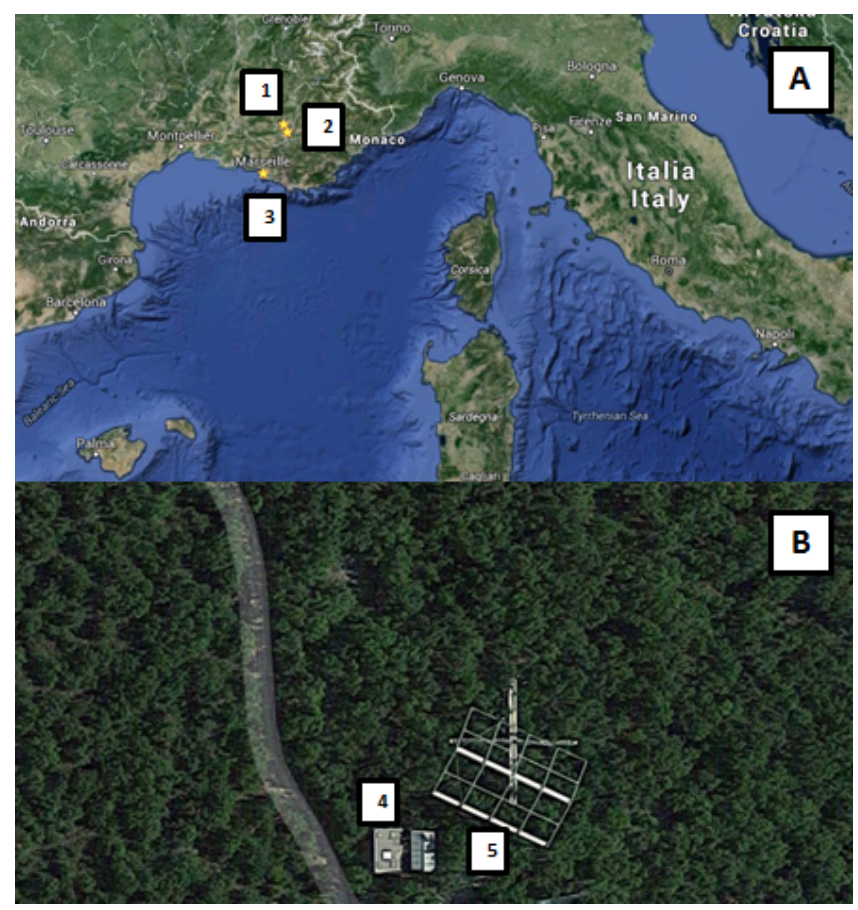

Figure 1. Site of Observatoire de Haute Provence (OHP) in the European map (a) and seen from above (b). Numbers refer to (1) OHP field site, (2) town of Manosque, (3) city of Marseille, (4) room for instruments measuring trace gases and (5) movable trailer for measuring $\mathrm{OH}$ reactivity.

ing spring 2012 (Kalogridis et al., 2014) and low intracanopy oxidation processes (Kalogridis et al., 2014).

$\mathrm{OH}$ reactivity was used as a tool to examine the reactive carbon budget and help assess the oxidative processes occurring through the canopy.

We measured total $\mathrm{OH}$ reactivity with the comparative reactivity method (CRM; Sinha et al., 2008) and used complementary measurements of trace gas concentrations to elucidate any missing reactivity pattern. We determined the $\mathrm{OH}$ reactivity and the trace gases at the same time and investigated two canopy heights: one inside the forest at $2 \mathrm{~m}$ and a second one above the forest at $10 \mathrm{~m}$.

\section{Methodology}

\subsection{Description of the field site}

We measured total $\mathrm{OH}$ reactivity and atmospheric gases concentrations at the oak observatory of the field site of OHP (http://www.obs-hp.fr), as part of the CANOPEE project (https://o3hp.obs-hp.fr/index.php/en/research/projects/

121-canopee-anr-jc-2011-en). Observatoire de Haute Provence is located in the Mediterranean region, southeast of France ( $5^{\circ} 42^{\prime} 44^{\prime \prime}$ E, $43^{\circ} 55^{\prime} 54^{\prime \prime} \mathrm{N}$; 650 m a.s.l.); Marseille is the closest largest city, about $100 \mathrm{~km}$ south $(\sim 1600000$ inhabitants), and Manosque is the closest town, about $18 \mathrm{~km}$ south from the site $(\sim 22000$ inhabitants; Fig. 1$)$.

The oak observatory (O3HP, https://o3hp.obs-hp.fr) was installed in 2009 within the OHP site in order to conduct field studies in ecology, plant phenology, microbiology and the atmosphere related to the third most abundant tree species in the French Mediterranean region. A geophysical sciences station (Gerard Megie) and an ICOS tower (Integrated Carbon Observation System, operative from 11 July 2014) also operate at OHP. The oak observatory is about 95 ha large and extends throughout a deciduous ecosystem dominated by downy oaks (Quercus pubescens Willd.) and Montpellier maple (Acer monspessulanum L.), which represent 75 and $25 \%$, respectively, of the overstorey canopy. Smokey bushes (Cotinus coggygria Scop.) and other grass species constitute the understorey canopy. The whole canopy is about $5 \mathrm{~m}$ high with an average leaf area index (LAI) measured during $\mathrm{Au}-$ gust 2010 of 2.4 (LAI-2000, Li-Cor, Lincoln, NE, USA). The climate at the site is typical of the Mediterranean area, with dry and hot summers and humid cool winters.

Downy oak is a tree species known to emit almost exclusively isoprene (about $99 \%$; see Genard-Zielinski et al., 2015) and due to its dominance in this forest it makes OHP a natural laboratory for focused studies on isoprene.

Our field work took place during 29 May-12 June 2014, as a followup experimental study of the works conducted during spring 2012 and published by Kalogridis et al. (2014) and Genard-Zielinski et al. (2015).

\subsection{Ambient air sampling}

We measured the total $\mathrm{OH}$ reactivity together with the concentrations of BVOCs emitted by the forest, their oxidation products and main atmospheric constituents. For these measurements we deployed the following techniques: the CRM (home built), a PTR-MS (Ionicon Analytik GmbH, Austria), a gas chromatography/flame ionization detector (GC-FID, Chromatotech, France), a formaldehyde analyzer through the Hantzsch reaction (Aero-Laser GmbH, Germany), offline analysis of sampling tubes through GC-MS (3800/2200 ion trap MS, Varian, USA) and a $\mathrm{NO}_{x}$ detector (Thermo Scientific, USA).

We sampled simultaneously $\mathrm{OH}$ reactivity and concentrations of VOC through two PFA sampling lines (OD 3/8") collocated on a mast, which was erected downwind the oak observatory. The two sampling lines, A and B, were directed to the main local A (Fig. 1, number 4) and to a movable trailer B (Fig. 1, number 5), respectively. Both lines ended with a manifold to provide the sampling flows to all the instruments. Sampling line A was split into lines directed to the PTR-MS, the GC-FID and the Hantzsch analyzer, which were all located in local A. Sampling line B was used for measuring $\mathrm{OH}$ reactivity and was split into a line for the zero air generator of the CRM and another for the ambient air sampling of the CRM. The sampling flows were driven by 
two pumps placed at the end of both manifolds. The flows and lines lengths were adjusted in order to have similar residence times of the species sampled through lines A and B that were, respectively, 23 and $13 \mathrm{~s}$. The lines' entire lengths were, respectively, 28 and $18 \mathrm{~m}$ for A and B; a joint union piece placed at $2 \mathrm{~m}$ on both lines allowed us to disconnect them and perform sampling at two different heights along the forest canopy by using the same line. Finally, both lines were insulated with black tubing and heated with a thermocouple type $\mathrm{K}$ by about $1{ }^{\circ} \mathrm{C}$ above ambient temperature in order to prevent gases condensation. Measurements with this sampling setup were performed sequentially on different days over the campaign period 29 May-12 June 2014 at two heights: 2 and $10 \mathrm{~m}$. With an average canopy height of $5 \mathrm{~m}$, air collection conducted at 2 and $10 \mathrm{~m}$ at OHP was used to elucidate the composition and reactivity of air masses inside and above the whole forest.

Extra sampling lines were used for GC-MS offline analysis, ozone and $\mathrm{NO}_{x}$ detection.

An autosampler (Sypac V2, Tera Environnement, France) was used to adsorb air on packed stainless steel sampling tubes with Tenax TA and Carbopack X as sorbent, for GCMS offline analysis of monoterpenes levels. In this case we used an independent extra line that was placed at $2 \mathrm{~m}$ on the mast. The sampling was performed every $3 \mathrm{~h}$ on specific days and relative speciation among the detected monoterpenes $(\alpha-$ pinene, $\beta$-pinene, myrcene, limonene) was used to determine the monoterpenes specific abundance and infer their amount from the total monoterpenes concentration, which instead was measured by PTR-MS.

In addition, $\mathrm{NO}_{x}\left(\mathrm{NO}+\mathrm{NO}_{2}\right)$ were sampled through an independent extra line placed on top of local A, at $4.3 \mathrm{~m}$ from the ground, about $15 \mathrm{~m}$ away from the mast. Ozone was monitored by the regional air quality network and its sampling line was placed a few hundred meters away from the main sampling site at $4.3 \mathrm{~m}$ from the ground.

\subsection{Comparative reactivity method and instrument performance}

Measurements of total $\mathrm{OH}$ reactivity were performed with a CRM instrument (home-built CRM; see Sinha et al., 2008, and Nölscher et al., 2012b, for more details on the CRM).

A CRM instrument consists of a glass flow reactor and a detector, in our case a commercial PTR-MS (quadrupole, Ionicon Analytik GmbH, Innsbruck, Austria). The concept of CRM is to produce a competition between a reference molecule, pyrrole $\left(\mathrm{C}_{4} \mathrm{H}_{5} \mathrm{~N}\right)$ and reactive molecules in ambient air to react with $\mathrm{OH}$ radicals generated inside the glass reactor. $\mathrm{OH}$ radicals are obtained from photolysis of water vapor with a pen ray $\mathrm{Hg}$ lamp, which emits at $184.9 \mathrm{~nm}$, placed inside one of the reactor arms. Pyrrole is first diluted in zero air and dry nitrogen, and its concentration is monitored on the PTR-MS at the protonated $m / z 68$ (C0). When the Hg lamp is switched on, pyrrole concentration decreases due to photolysis and its concentration is monitored as $\mathrm{C} 1$. Then, the flow of nitrogen passes through a bubbler and water vapor is transported to the lamp to achieve photolysis and production of $\mathrm{OH}$; in this stage pyrrole reacts with $\mathrm{OH}$ (rate coefficient $=1.2 \times 10^{-10} \mathrm{~cm}^{3}$ molecule ${ }^{-1} \mathrm{~s}^{-1}$ at $25^{\circ} \mathrm{C}$; Atkinson et al., 1984 and Dillon et al., 2012) and C2 is monitored. A four-way valve permits fast switches between zero air and ambient air; when the latter dilutes pyrrole, the competition for $\mathrm{OH}$ radicals takes place and $\mathrm{C} 3$ is the measured concentration of pyrrole. $\mathrm{C} 3$ differs from $\mathrm{C} 2$ depending on the amount and type of reactive molecules present in ambient air. Differences between C 2 and C 3 are used to determine the total $\mathrm{OH}$ reactivity from the following equation:

$R_{\mathrm{air}}=\frac{(\mathrm{C} 3-\mathrm{C} 2)}{(\mathrm{C} 1-\mathrm{C} 3)} \cdot k_{\text {pyrrole }+\mathrm{OH}} \cdot \mathrm{C} 1$.

Equation (1) assumes that the reaction between pyrrole and $\mathrm{OH}$ is in the pseudo-first-order kinetics, i.e., [pyrrole $]>>[\mathrm{OH}]$.

Reactivity in ambient air is obtained every $10 \mathrm{~min}$ (calculated from $5 \mathrm{~min}$ on $\mathrm{C} 2$ and $5 \mathrm{~min}$ on $\mathrm{C} 3$ ) and raw values are corrected for humidity differences between the levels $\mathrm{C} 2$ and C3, deviation from first-order kinetics and dilution inside the reactor (Zannoni et al., 2015). Humidity differences between $\mathrm{C} 2$ and $\mathrm{C} 3$ can affect the concentration of $\mathrm{OH}$ radicals produced inside the reactor and can lead to an underestimation or overestimation of the measured $\mathrm{OH}$ reactivity. We generated zero air to produce $\mathrm{C} 2$ by sampling ambient air through a zero air generator, which removes the VOCs present in ambient air and leaves the air flow with the same humidity of ambient air. In our case, small differences in humidity were still observed and corrected (13\% decrease of the raw value).

We tested the performance of the CRM before and during the field campaign through injections of a known amount of $\mathrm{OH}$ reactivity generated by external gas standards. For this purpose, we used a standard of propane, which has a medium reactivity towards $\mathrm{OH}$ $\left(k_{\text {propane }+\mathrm{OH}}=1.1 \times 10^{-12} \mathrm{~cm}^{3}\right.$ molecule ${ }^{-1} \mathrm{~s}^{-1}$; Atkinson et al., 1997), and isoprene, which instead is very reactive towards $\mathrm{OH}\left(k_{\text {isoprene }+\mathrm{OH}}=1 \times 10^{-10} \mathrm{~cm}^{3}\right.$ molecule $^{-1} \mathrm{~s}^{-1}$; Atkinson, 1986) and represents the main component of the air parcels sampled in this specific forest. Injections were performed over a range of pyrrole/OH ratio between 2 and 9 , with 9 being the closest to pseudo-first-order kinetics regime. The reactivity measured plotted against the reactivity injected with the two mentioned standards gave a slope of $1.01 \pm 0.04(1 \sigma)$ with an $R^{2}$ of 0.96 up to reactivity values of $500 \mathrm{~s}^{-1}$. The correction factor (slope of injected reactivity versus measured reactivity) is plotted versus the pyrrole-to$\mathrm{OH}$ ratio and used to correct the raw reactivity for deviations in the kinetics regime (see Supplement). For this study such correction determined a $47 \%$ decrease of the raw data of reactivity. Corrections for humidity were obtained by averaging the results of three main tests conducted during the field campaign and were comparable to the results obtained in the 
laboratory (19\% standard deviation among results). Calibrations of the PTR-MS for dry and wet pyrrole were carried out at the beginning and end of the field campaign and showed a very good agreement between each other (difference within $1 \%$ for the dry calibration factor and $4 \%$ for the wet calibration factor). It is necessary to calibrate pyrrole at dry and wet conditions due to differences in sensitivity reported by the PTR-MS operating at different ambient humidity (Sinha et al., 2010).

During the days dedicated to the sampling of trace gases, we measured $\mathrm{OH}$ reactivity for only 5 days ( 3 days inside the canopy and 2 days above the canopy) due to the time needed to accurately test the performance of our instrument on the field, settings adjustment and tests needed to process the raw data.

Our instrument performs measurements between the limit of detection ( $\mathrm{LoD})$ of the instrument $\left(3 \mathrm{~s}^{-1}, 3 \sigma\right)$ up to $500 \mathrm{~s}^{-1}$ with an overall systematic uncertainty of $35 \%(1 \sigma)$. More information on our instrument can be found in Zannoni et al. (2015).

\subsection{Complementary measurements at the field site}

We measured the concentration of BVOCs emitted from the forest, their oxidation products and main atmospheric constituents. Concentrations are used to calculate the $\mathrm{OH}$ reactivity at the site with Eq. (2) and the species-specific relative contribution.

$R=\sum_{i} k_{i+\mathrm{OH}} \cdot X_{i}$

where $i$ is any measured compound listed in Table 1 . The error on the calculated value of $\mathrm{OH}$ reactivity is estimated by considering the propagation of the $1 \sigma$ uncertainty on the rate constant of reaction between $\mathrm{OH}$ and the measured compound and the $1 \sigma$ uncertainty associated with the concentration of the measured compound.

\subsubsection{Proton transfer reaction/mass spectrometer}

We used a PTR-MS (high-sensitivity quadrupole, Ionicon Analytik, Austria) operated under standard conditions $\left(p_{\text {drift }}=2.2 \mathrm{mbar}, E / N=135 \mathrm{Td}\left(1 \mathrm{Td}=10^{-17} \mathrm{~cm}^{-1}\right)\right.$, $T_{\text {inlet }}=60^{\circ} \mathrm{C}$ ) to record the concentrations of trace gases at the site (Lindinger and Jordan, 1998). We sampled the air masses in the scan mode and inspected all species with protonated mass from $\mathrm{m} / \mathrm{z} 21$ to $\mathrm{m} / \mathrm{z}, 138$ with cycles of $5 \mathrm{~min}$ each. Sampling in the scan mode procedure was revealed to be a convenient way to analyze unknown air parcels.

We calibrated the instrument using a gas calibration unit (GCU, Ionicon Analytik, Austria) with a standard gas mixture (GCU, Ionicon Analytik, Austria) containing methanol $(\mathrm{m} / \mathrm{z} 33)$, acetonitrile $(\mathrm{m} / \mathrm{z} 42)$, acetaldehyde $(m / z 45)$, acrolein $(m / z 57)$, acetone $(m / z 59)$, isoprene $(m / z 69)$, crotonaldehyde $(m / z 71)$, methyl ethyl ketone $(\mathrm{m} / \mathrm{z} 73)$, benzene $(\mathrm{m} / z$ 79), toluene $(\mathrm{m} / z 93)$ and $\alpha$-pinene $(\mathrm{m} / z$ 137); see Table 2 for the list of compounds, their protonated mass, mean sensitivity from field calibrations and mass LoD. Calibrations were run over the range $0-20 \mathrm{ppbv}$ at the beginning and at the end of the field campaign, with no significant change in the detector sensitivity (differences up to $10 \%$ and for most species within $5 \%$ ); therefore we used a mean calibration factor for the whole campaign.

Volume mixing ratios for the calibrated species were obtained following the procedure of Taipale et al. (2008). Mixing ratios for the non-calibrated species were obtained from the transmission curve of the instrument and the speciesspecific transmission coefficient. Correlations within mixing ratios obtained from calibration and transmission coefficients for calibrated species showed a good/fair agreement $\left(R^{2}\right.$ for $m / z 33, m / z, 45$ and $m / z 69$ was, respectively, $0.81,0.86$ and $0.43)$.

We used a GC/FID to cross-validate the concentration obtained for isoprene, which is the dominant compound at the site, usually measured at the protonated $m / z 69$ with the PTR-MS but often prone to fragmentation in the drift tube (see Sect. 2.4.2). All the measured species, except isoprene, were not cross-validated, and their mass identification was obtained according to the existing studies conducted at similar sites (e.g., Kalogridis et al., 2014; Holzinger et al., 2002; Warneke et al., 2001). This is the case in particular for masses $m / z 71$ and $m / z 73$. The former has usually been attributed to the sum of MVK (methyl vinyl ketone) and MACR (methacrolein), the most abundant oxidation products of isoprene. Recent studies have highlighted that another group of compounds, the isoprene hydroperoxides (ISOPOOH), mostly originated from isoprene oxidation in unpolluted environments can also fragment at $m / z 71$ in the PTR-MS (Liu et al., 2013; Rivera-Rios et al., 2014). Since we did not separate these compounds, and we conducted our field work in an unpolluted environment where the ISOPOOH might have been produced, we will refer hereinafter to $m / z 71$ as the sum of the isoprene oxidation products ISOP.OXs: MVK + MACR + isoprene hydroperoxides (ISOPOOH). Mass-to-charge 73, here reported as methyl ethyl ketone (MEK) and calibrated as such, can have several interferences. Among the possible interferences we speculate the presence of methylglyoxal, a compound generated during the degradation path of isoprene, which is the most abundant compound measured at our site.

\subsubsection{Gas chromatography/flame ionization detector}

A gas chromatograph equipped with a GC-FID (airmoVOC C2-C6, Chromatotec, Saint Antoine, France) was deployed to sample hydrocarbons in the fraction $\mathrm{C} 2-\mathrm{C} 6$, with a time resolution of $30 \mathrm{~min}$ ( $10 \mathrm{~min}$ sampling followed by $20 \mathrm{~min}$ analysis). The instrument sampled ambient air with a flow rate of $18 \mathrm{sccm}$ via a stainless steel inlet. Ambient air passed through a Nafion dryer, then to a preconcentration trap 
Table 1. Measured species (except for $\mathrm{CO}$ and methane whose concentrations were assumed) used for calculating $\mathrm{OH}$ reactivity.

\begin{tabular}{ll}
\hline Family group & Species name \\
\hline Alkanes & $\begin{array}{l}\text { methane; ethane; propane; n-butane; i-butane; n-pentane; } \\
\text { i-pentane; 2,2-dimethylbutane; cyclohexane; hexane } \\
\text { ethylene; propene; 1-butene; i-butene; cis-2-butene; 1,3-butadiene; } \\
\text { trans-2-pentene; 1-pentene; cis-2-pentene; trans-2-butene }\end{array}$ \\
& $\begin{array}{l}\text { acetylene } \\
\text { Alkenes }\end{array}$ \\
Aromatics & $\begin{array}{l}\text { isoprene; } \text { MVK+MACR+ISOPOOH; } \alpha \text {-pinene; } \\
\text { Biogenics }\end{array}$ \\
Oxygenates & $\begin{array}{l}\text { formaldehyde; acetaldehyde; methanol; } \\
\text { acetone; methyl ethyl ketone }\end{array}$ \\
& $\mathrm{CO} ; \mathrm{NO} ; \mathrm{NO}_{2}$
\end{tabular}

Table 2. Name and mass of VOCs included in the standard mixture used for calibrating the PTR-MS. Reported sensitivities correspond to mean values of calibrations performed during the campaign. Limits of detection (LoDs) correspond to $3 \sigma$ of the standard deviation.

\begin{tabular}{llrr}
\hline \multicolumn{3}{c}{ VOCs contained in the calibration gas standard } \\
\hline$m / z$ & Identified compound & $\begin{array}{r}S_{\text {norm }} \\
\left(\text { ncps ppbv }^{-1}\right)\end{array}$ & $\begin{array}{r}\text { LoD } \\
(\mathrm{ppbv})\end{array}$ \\
\hline 33 & Methanol & 11.0 & 0.72 \\
42 & Acetonitrile & 19.0 & 0.12 \\
45 & Acetaldehyde & 16.5 & 0.26 \\
57 & Ethyl ketone & 17.6 & 0.09 \\
59 & Acetone & 20.9 & 0.15 \\
69 & Isoprene & 6.6 & 0.19 \\
71 & Crotonaldehyde & 21.0 & 0.22 \\
73 & MEK & 18.6 & 0.11 \\
79 & Benzene & 9.9 & 0.13 \\
93 & Toluene & 10.5 & 0.08 \\
137 & $\alpha-$ Pinene & 2.7 & 0.08 \\
\hline
\end{tabular}

cooled down to $-8^{\circ} \mathrm{C}$, filled with Carboxen, Carbopack B and Carbotrap $\mathrm{C}$, and finally thermodesorbed at $220^{\circ} \mathrm{C}$ and injected on-column into a metal capillary column (Porous Layer Open Tubular Column PLOT, $\mathrm{Al}_{2} \mathrm{O}_{3} / \mathrm{KCl} ; 0.53 \mathrm{~mm}$ inner diameter and $25 \mathrm{~m}$ length, Varian Inc, USA). Calibrations were performed twice per week with a certified standard VOC mixture (National Physical Laboratory, UK). The overall uncertainty was estimated to be $15 \%(1 \sigma)$. Correlation between isoprene measured by GC-FID and $m / z 69$ identified as the protonated isoprene mass over $30 \mathrm{~min}$ averaged data showed differences within $14 \%$ among the two instruments (isoprene GC-FID $=0.86$ (isoprene PTR-MS $_{\text {) }}, R^{2}=0.93$ ).

\subsubsection{Formaldehyde analyzer}

Formaldehyde (HCHO) was measured with a commercial Aero-Laser analyzer (AL-4021, Aero-Laser GmbH, Germany). The technique, a continuous liquid fluorimetry, has been described in detail elsewhere (Dasgupta et al., 1988). Briefly, gaseous $\mathrm{HCHO}$ was scrubbed into a diluted sulfuric acid solution in a stripping coil thermostated at $+10^{\circ} \mathrm{C}$. A fluorescent compound was quantitatively produced at $+70^{\circ} \mathrm{C}$ by the reaction of the liquid solution with the Hantzsch reagent (i.e., a dilute mixture of acetyl acetone, acetic acid and ammonium acetate) and subsequently detected at $510 \mathrm{~nm}$.

The working conditions applied to the AL 4021 for this study were similar to those applied previously for the same device in two HCHO studies conducted in Antarctica (Preunkert and Legrand, 2013; Preunkert et al., 2015). In brief, liquid reagents were prepared from analytical grade chemicals (Merck, USA) and ultrapure water (18 megohm, TOC $<1$ ppbv, Elga Labwater); the air flow was kept at 1000 sccm, which ensured a stripping efficiency of more than $99 \%$. Raw data were collected with a time resolution of $30 \mathrm{~s}$. Gas standard calibrations and background levels took 50 and $25 \mathrm{~min}$ and were performed every 12 and $3 \mathrm{~h}$, respectively. A mean detection limit of $42 \pm 16 \mathrm{pptv}$ is calculated as twice the standard deviation of the raw data $(30 \mathrm{~s})$ obtained during the 121 zero measurements made during the campaign, which was consistent with the typical LoD achieved $(\sim 30$ pptv) with the same analyzer in the above-cited previous studies.

To minimize the effects of temperature changes on the field (see details in Preunkert et al., 2013), the instrument was placed in a thermostated box at $24^{\circ} \mathrm{C}$. A Teflon filter $(47 \mathrm{~mm}$ diameter) was placed on the sampling line between the manifold (see Sect. 2.2) and the HCHO analyzer to prevent large particles (e.g., plant debris) entering the instrument. A comparison conducted on the field between line A (see Sect. 2.2, including the Teflon filter) and a $3 \mathrm{~m}$ long PTFE line (OD $1 / 4$ ") connected directly to the analyzer confirmed that no significant contamination or loss of $\mathrm{HCHO}$ was present with this setup. 


\subsubsection{NO $x$ analyzer}

Nitrogen oxides were measured with a commercial instrument (17i model, Thermo Scientific, USA), based on chemiluminescence. Its calibration was performed after the field campaign, where a LoD of $0.3 \mathrm{ppbv}(2 \sigma)$ and a precision of \pm 0.4 ppbv were estimated.

Nitrogen oxides were sampled at $15 \mathrm{~m}$ from the main sampling site; hence we assumed that their concentration inside and above the canopy was not affected by any significant change.

\subsubsection{GC-MS offline analysis}

Adsorbing stainless steel sampling tubes with Tenax TA and Carbopack $\mathrm{X}$ as sorbents were used to sample monoterpenes as $\alpha$-pinene, $\beta$-pinene, $\beta$-myrcene and limonene for off-line analysis with a GC-MS (3800/2200 ion trap MS, Varian, USA). Sampling was conducted at ambient temperature with an autosampler (Sypac V2, Tera Environnement, France) every $3 \mathrm{~h}$, tubes were then stored at $4{ }^{\circ} \mathrm{C}$ and analyzed within 1 month in the laboratory. Ozone was removed from the tubes prior to the sampling procedure by using $\mathrm{MnO}_{2}$-coated copper nets according to the procedure reported in Larsen et al. (1997). Concentrations of individual monoterpenes were then used to infer their relative abundance from the total monoterpenes concentration obtained with the PTR-MS and calculate their contribution to the $\mathrm{OH}$ reactivity.

\subsection{6 $\mathrm{O}_{3}, \mathrm{CH}_{4}, \mathrm{CO}$}

Ozone is constantly monitored at OHP from the regional air quality network Air-Paca, France (http://www.atmopaca. org/). The monitor is placed in a container located at a distance of a few hundred meters from the sampling site. Methane and carbon monoxide mean concentrations were derived based on measurements conducted during spring 2012 and considered to be $1900 \mathrm{ppbv}$ and $108 \pm 16 \mathrm{ppbv}$, respectively.

\subsubsection{Meteorological parameters}

Meteorological parameters such as temperature, relative humidity (CS215, Campbell Scientific, UK), photosynthetical active radiation (PAR; LI-190, Li-Cor, Lincoln, NE, USA), wind speed and wind direction were acquired through sensors already available at the measurements site $\left(\mathrm{O}_{3} \mathrm{HP}\right.$ website: https://o3hp.obs-hp.fr/index.php/fr/). In this work we used data collected at 2 and at $6 \mathrm{~m}$ to help with discussion of the results inside the canopy and above the canopy, respectively.
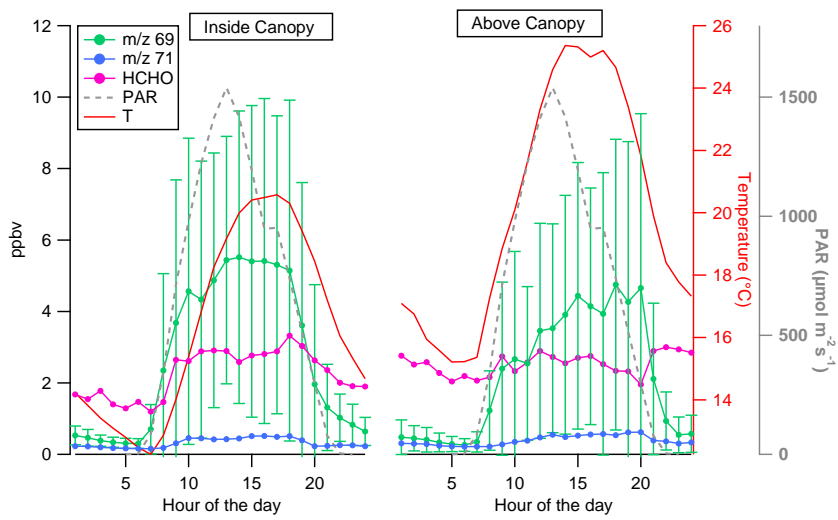

Figure 2. Daily mean of $m / z 69, m / z 71$, HCHO (ppbv), temperature and PAR for days of measurements at $2 \mathrm{~m}$ (left panel) and at $10 \mathrm{~m}$ (right panel) of the field campaign. Bars on $\mathrm{m} / \mathrm{z} 69$ correspond to $\pm 1 \sigma$ standard deviation. PAR data were collected at $6 \mathrm{~m}$ for both cases. Temperature data were collected at $2 \mathrm{~m}$ and at $6.15 \mathrm{~m}$.

\section{Results}

\subsection{Trace gas mixing ratio}

During the first campaign week we observed some peaks of contamination for about $1 \mathrm{~h}$ every morning due to emissions from car exhausts. Such data points were filtered from the data sets that will be discussed in this section.

Figures 2 and 3 illustrate diurnal profiles and time series of $m / z 69$, identified as isoprene, its main degradation products $m / z 71$, identified as MVK+MACR+ISOPOOH and here referred to as ISOP.OXs (isoprene oxidation products), and $\mathrm{HCHO}$, together with meteorological parameters as air temperature and PAR, at both sampling heights. Figure 2 shows that these compounds have clear diurnal profiles; however, while isoprene has similar profiles to PAR and temperature, its degradation products tend to increase after isoprene increases, which confirms the main secondary origin of such species. Isoprene mean values peak when temperature is highest: during the afternoon inside the canopy (14:00 CEST, left panel) and during the late afternoon above the canopy (20:00, right panel). The latter peak measured so late above the canopy is driven by the enhanced ambient temperature measured on 8 June 2014 (represented in Fig. 6). Formaldehyde mixing ratios are higher than $m / z 71$ for both heights; inside the canopy its profile is clearly diurnal, while above the canopy it looks more stable, mostly because of the higher nighttime level reached on 8 June 2014 (see Fig. 3).

Time series are reported in Fig. 3 for the whole campaign period, from 29 May to 12 June 2014, with different colors indicating the air masses sampled at $2 \mathrm{~m}$ (data reported with the green line) and at $10 \mathrm{~m}$ (data reported with the blue line). All species show a progressive increase towards the end of the field campaign, when air temperature at the site was higher compared to the first days of measurements. Data 


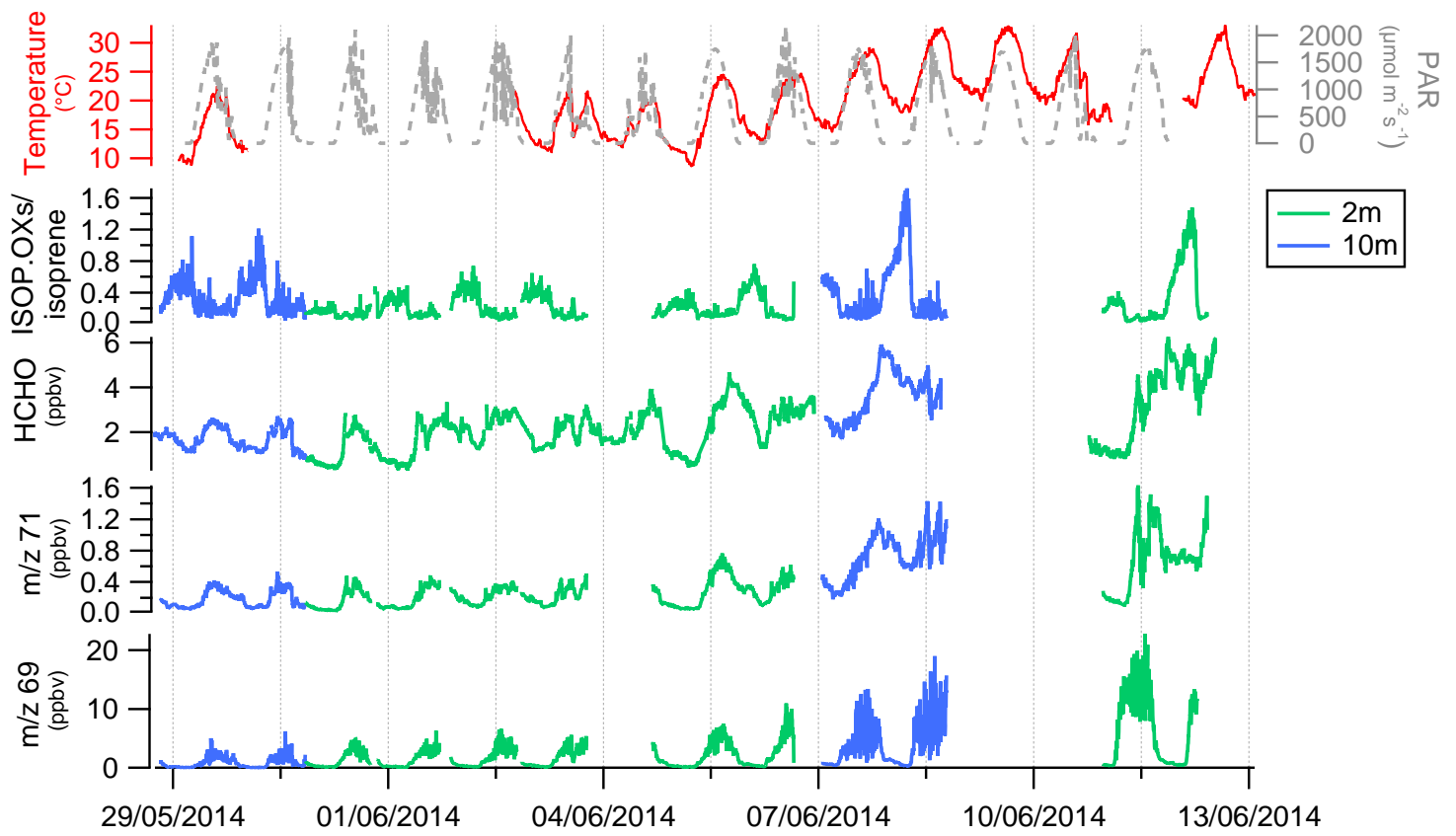

Figure 3. Time series of $m / z 69$ (isoprene), $m / z 71$ (ISOP.OXs $=$ MVK+MACR+ISOPOOH), HCHO and ISOP.OXs/isoprene during the field campaign at OHP. Data were collected inside the canopy ( $2 \mathrm{~m}$, green line) and above the canopy (10m, blue line) on different days. Temperature and PAR measured at $6 \mathrm{~m}$ are reported as reference on the top panel.

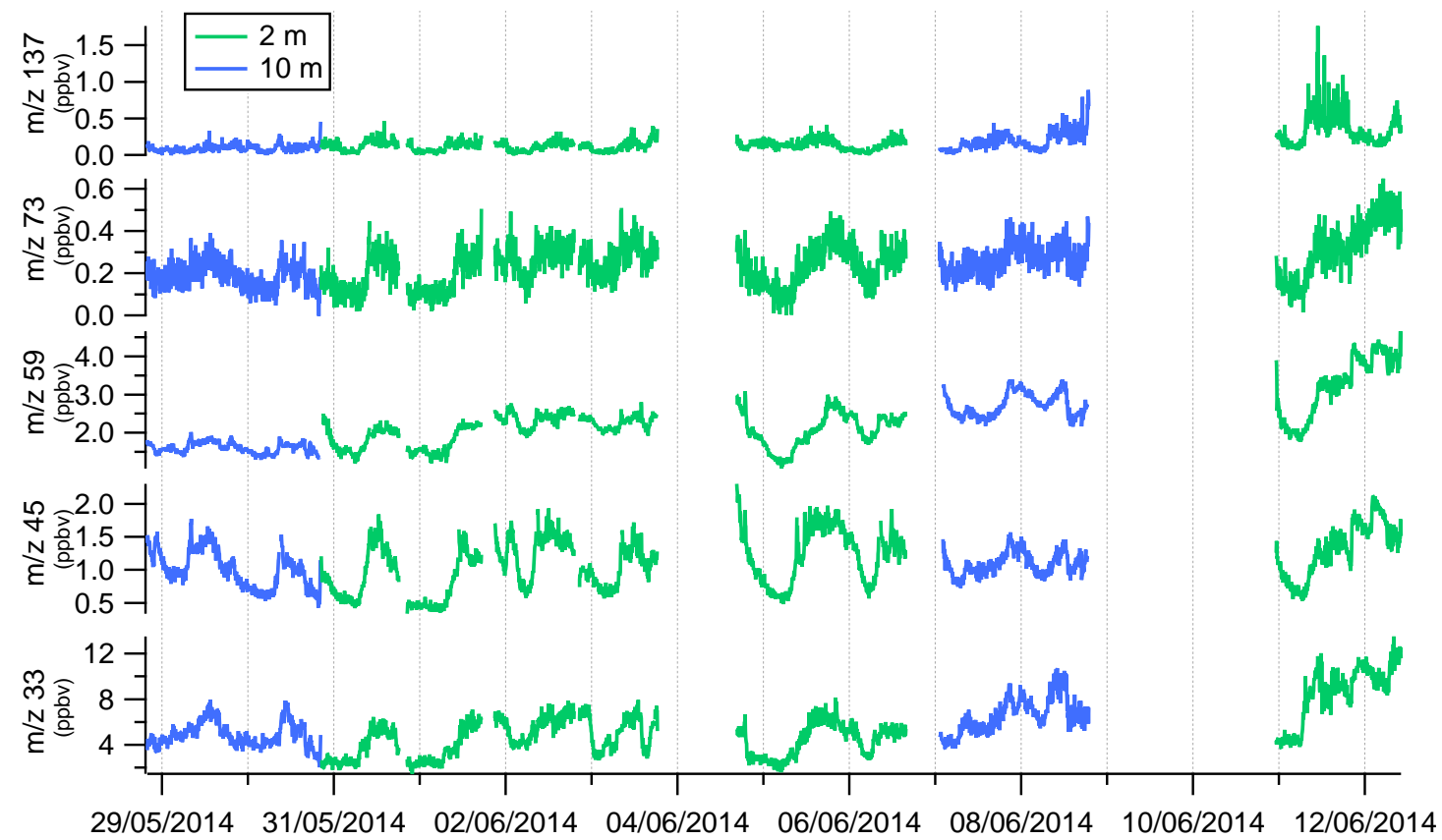

Figure 4. Time series of $m / z 33$ (methanol), $m / z 45$ (acetaldehyde), $m / z 59$ (acetone), $m / z 73$ (methyl ethyl ketone) and $m / z$ 137 (monoterpenes) inside ( $2 \mathrm{~m}$, green line) and above (10 $\mathrm{m}$, blue line) the canopy at OHP. 
Table 3. Volume mixing ratios inside and above the canopy of targeted molecules sampled with the PTR-MS.

\begin{tabular}{|c|c|c|c|c|c|c|c|c|c|}
\hline \multirow[b]{2}{*}{$m / z$} & \multirow[b]{2}{*}{$\begin{array}{l}\text { Identified } \\
\text { compound }\end{array}$} & \multicolumn{4}{|c|}{ Volume mixing ratios inside the canopy ( $2 \mathrm{~m}$; ppbv) } & \multicolumn{4}{|c|}{ Volume mixing ratios above the canopy ( $10 \mathrm{~m}$; ppbv) } \\
\hline & & Mean $24 \mathrm{~h}$ & $\begin{array}{r}\text { Mean day } \\
(06: 30-22: 00)\end{array}$ & $\begin{array}{r}\text { Mean night } \\
(22: 00-06: 30)\end{array}$ & Daily max & Mean $24 \mathrm{~h}$ & $\begin{array}{r}\text { Mean day } \\
(06: 30-22: 00)\end{array}$ & $\begin{array}{r}\text { Mean night } \\
(22: 00-06: 30)\end{array}$ & Daily max \\
\hline 33 & Methanol & $5.4 \pm 0.7$ & $5.4 \pm 0.5$ & $4.4 \pm 0.4$ & $2.8-13.5$ & $5.5 \pm 0.1$ & $5.7 \pm 0.4$ & $4.8 \pm 0.2$ & $7.9-11.2$ \\
\hline 45 & Acetaldehyde & $1.2 \pm 0.1$ & $1.2 \pm 0.2$ & $0.9 \pm 0.1$ & $1.2-5$ & $1 \pm 0.08$ & $1.2 \pm 0.1$ & $1 \pm 0.09$ & $1.8-6.4$ \\
\hline 59 & Acetone & $2.4 \pm 0.7$ & $2.4 \pm 0.6$ & $2.2 \pm 0.2$ & $2.3-10$ & $2.1 \pm 0.2$ & $2 \pm 0.3$ & $2.1 \pm 0.1$ & $2-7.1$ \\
\hline 69 & Isoprene & $2.5 \pm 1.8$ & $3.5 \pm 1.5$ & $0.5 \pm 0.2$ & $1.2-22.8$ & $2.3 \pm 1.7$ & $2.8 \pm 1.5$ & $0.4 \pm 0.2$ & $5.1-19$ \\
\hline 71 & ISOP.OXs & $0.3 \pm 0.1$ & $0.4 \pm 0.1$ & $0.2 \pm 0.03$ & $0.1-1.6$ & $0.4 \pm 0.08$ & $0.4 \pm 0.1$ & $0.28 \pm 0.05$ & $0.4-1.4$ \\
\hline 79 & Benzene & $0.04 \pm 0.02$ & $0.04 \pm 0.01$ & $0.03 \pm 0.01$ & $0.1-0.4$ & $0.07 \pm 0.01$ & $0.11 \pm 0.01$ & $0.07 \pm 0.01$ & $0.1-0.4$ \\
\hline 93 & Toluene & $0.05 \pm 0.01$ & $0.05 \pm 0.01$ & $0.04 \pm 0.01$ & $0.08-0.7$ & $0.06 \pm 0.01$ & $0.07 \pm 0.02$ & $0.05 \pm 0.01$ & $0.2-0.5$ \\
\hline 137 & Monoterpenes & $0.18 \pm 0.07$ & $0.21 \pm 0.08$ & $0.11 \pm 0.03$ & $0.3-1.8$ & $0.14 \pm 0.05$ & $0.15 \pm 0.05$ & $0.08 \pm 0.01$ & $0.4-0.9$ \\
\hline
\end{tabular}

collected between 7 and 12 June 2014 above and inside the canopy can be directly compared, based on similar conditions of temperature and solar radiation. Maximum values for isoprene inside and above the canopy are close (maximum at $10 \mathrm{~m}$ is $19 \mathrm{ppbv}$, maximum at $2 \mathrm{~m}$ is $23 \mathrm{ppbv}$ ) and small differences can be explained mainly on a dilution basis, a better mixing of air masses reached above the canopy height due to the sparse canopy structure. Interestingly, high levels of $m / z 71$ and $\mathrm{HCHO}$ were recorded during the nights between 7 and 8 and between 11 and 12 June. Such high nighttime concentrations are also observed for other chemical species (see text below). Figure 4 illustrates time series for masses $m / z 33, m / z 45, m / z 59, m / z 73$ and $m / z 137$, identified, respectively, as methanol, acetaldehyde, acetone, methyl ethyl ketone and sum of monoterpenes. Monoterpenes are primary emitted biogenic compounds while the other species can have both primary and secondary origins (Jacob et al., 2002, 2005; Millet et al., 2010). Methanol has a daily maximum of $14 \mathrm{ppbv}$ (inside the canopy), which makes it the second most abundant compound measured at OHP after isoprene (daily max inside the canopy 23 ppbv), followed by acetone, acetaldehyde, monoterpenes, ISOP.OXs, toluene and benzene, in order of abundance (Table 3). Over $24 \mathrm{~h}$, methanol is instead the first most abundant compound at OHP, followed by isoprene, acetone and acetaldehyde. Both methanol and isoprene have a diurnal profile, but methanol has a longer lifetime compared to isoprene (estimated to be 12 days and $1.4 \mathrm{~h}$, respectively; see Atkinson and Arey, 2003); therefore over $24 \mathrm{~h}$ the former shows less variability in the atmosphere.

During the two nights mentioned above ( 8 and 12 June) the concentration of the oxygenated compounds was higher compared to the other nights. More discussion on this behavior is provided in Sect. 3.4.

Anthropogenic hydrocarbons mixing ratios in the fraction C2-C6 were individually below $1.5 \mathrm{ppbv}$, with ethane being the most abundant (mean over the campaign $=0.9 \pm 0.2 \mathrm{ppbv}$ ), followed by acetylene, ethylene and isopentane. Anthropogenic tracers measured by PTRMS showed the same trend and confirmed the poor anthropogenic influence at this forested site: benzene maximum was $0.41 \mathrm{ppbv}$, the mean over $24 \mathrm{~h}$ was $0.04 \mathrm{ppbv}$, toluene was maximum $0.69 \mathrm{ppbv}$ and its mean over $24 \mathrm{~h}$ was 0.05 ppbv. Concentrations of $\mathrm{NO}$ and $\mathrm{NO}_{2}$ were maximum 1.7 and $5 \mathrm{ppbv}$ with a mean value of $0.45 \pm 0.38 \mathrm{ppbv}$ and $3.4 \pm 0.49$ ppbv during the whole campaign, respectively. Ozone concentration ranged within $21-78 \mathrm{ppbv}$, with a mean value of $47 \pm 10 \mathrm{ppbv}$. The highest values of ozone, often observed in the afternoon, are due to regional transport from air masses impacted by anthropogenic emissions (usually from the area of Marseille). Therefore the site can be, depending on air mass origin, regionally influenced by anthropogenic plumes. Nevertheless, the low levels of anthropogenic primary compounds suggest that this anthropogenic contribution is low. Additionally, we noticed that during the campaign the dominant wind direction was from north; hence the site was mostly exposed to the influence of the oak forest.

Values discussed herein can be compared to values measured during the field work conducted at OHP during spring 2012 (compare Table 3 in this work with Table 2 in Kalogridis et al., 2014). Both field works were conducted during the same season (late spring, beginning of June), with the site exposed to slightly different temperature levels (daily maximum in $201230^{\circ} \mathrm{C}$, daily maximum in $201431.5^{\circ} \mathrm{C}$ ), but the sampling was performed in different portions of the forest, with a distance between each other of a few hundreds of meters. It is interesting to notice that atmospheric levels of VOCs are close only for anthropogenic species while all biogenic species and oxygenated compounds have almost doubled from 2012 to 2014. The same isoprene-temperature dependence was achieved during the two experimental works, which demonstrates that the higher mean concentration of biogenic compounds observed in 2014 was probably due to the higher mean temperature during the second campaign.

\subsection{Total $\mathrm{OH}$ reactivity}

Figures 5 and 6 report $30 \mathrm{~min}$ averaged values of total $\mathrm{OH}$ reactivity inside and above the canopy during 11-12 and 78 June 2014, respectively, with the black line and associated error bars (overall uncertainty $35 \%, 1 \sigma$ ). At $2 \mathrm{~m} \mathrm{OH}$ reactivity varied between the instrumental LoD and $69 \mathrm{~s}^{-1}$ and was on average $26 \pm 19 \mathrm{~s}^{-1}$. At $10 \mathrm{~m}$ it varied between the LoD 


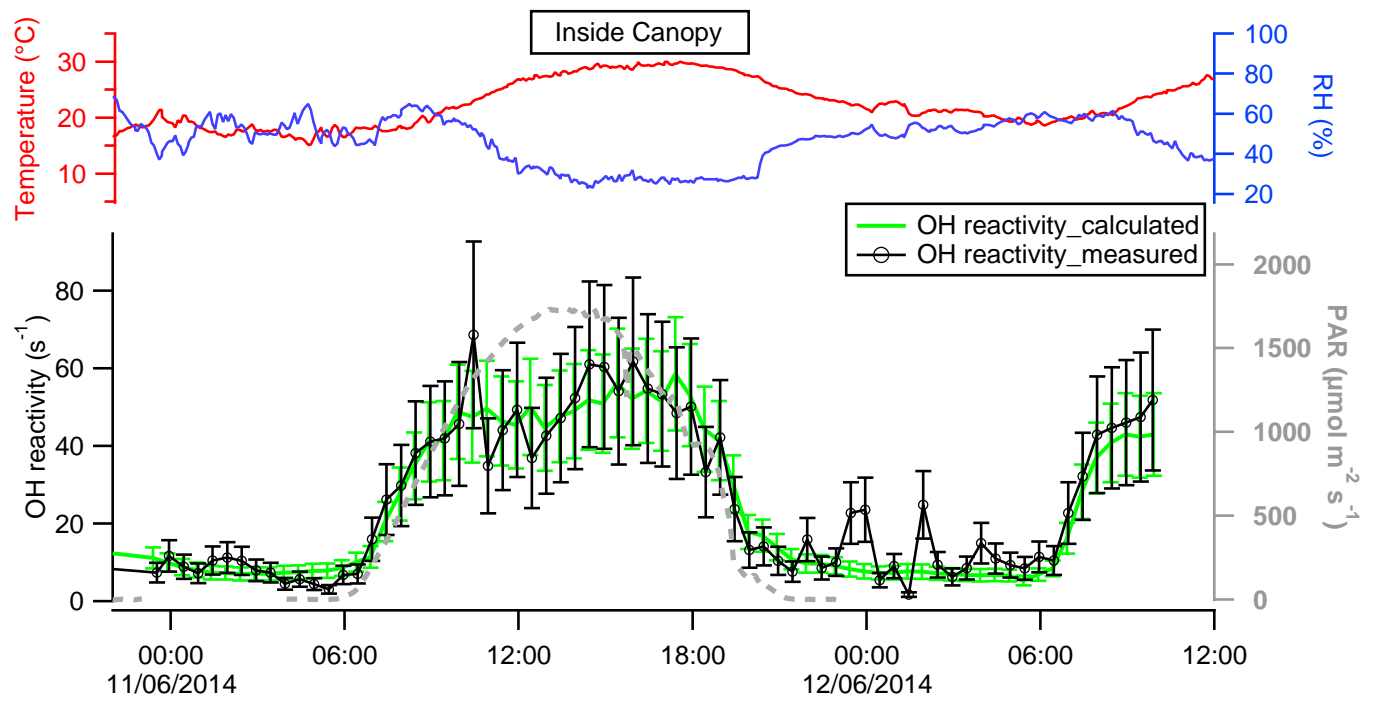

Figure 5. Total OH reactivity measured (black line and markers) with the comparative reactivity method (CRM) and calculated OH reactivity from measured concentrations of trace gases (green line) on the left axes, photosynthetical active radiation on the right axes (gray dashed line) and temperature and relative humidity on the left and right upper axes (red and blue lines). Data points represent 30 min averages of the sampled data and error bars correspond to 35 and $25 \%(1 \sigma)$ instrumental uncertainties. Data refer to air sampled inside the canopy at $2 \mathrm{~m}$ height.

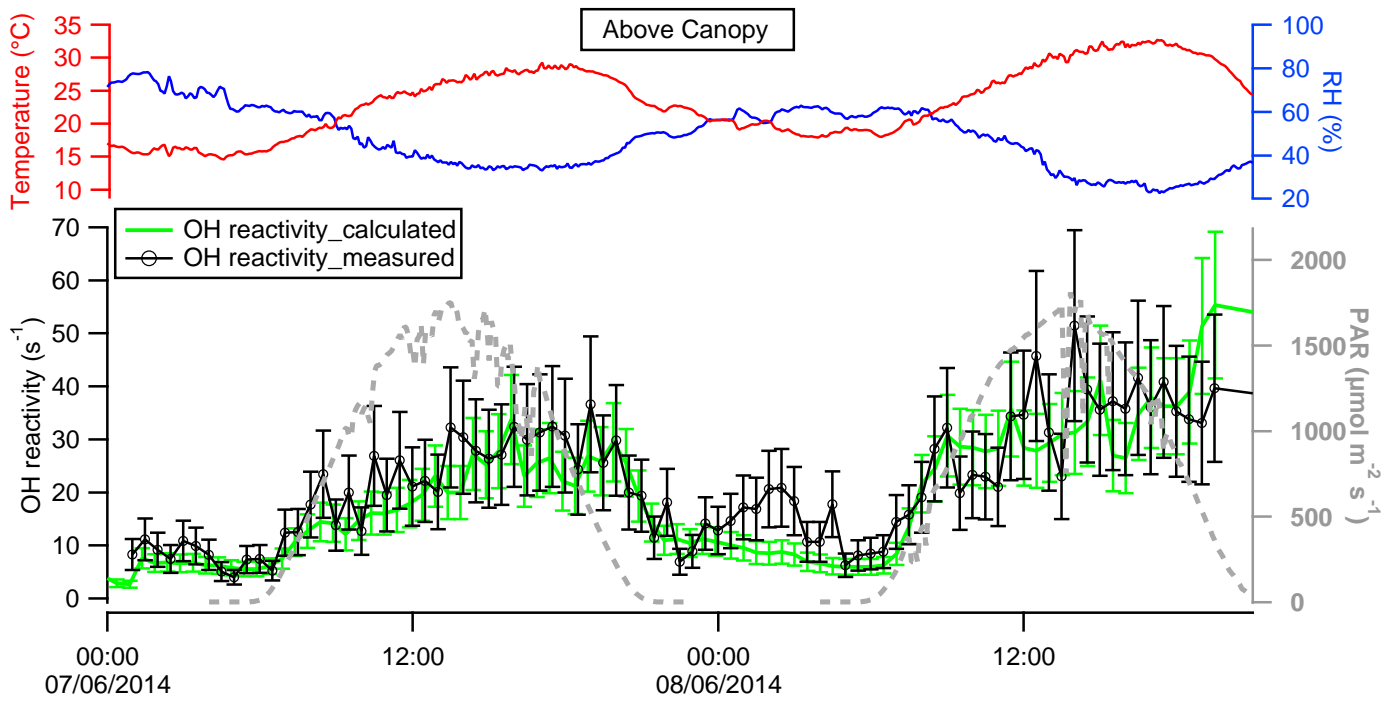

Figure 6. Total $\mathrm{OH}$ reactivity measured (black line and markers) and $\mathrm{OH}$ reactivity calculated (green line) above the canopy at $10 \mathrm{~m}$ height. Temperature (red line), RH (blue line) and PAR (gray dashed line) are reported for reference. Data points represent 30 min averages over the data collected. Uncertainties correspond to 35 and $25 \%$ for the measured and calculated reactivity, respectively $(1 \sigma)$.

and a maximum of $68 \mathrm{~s}^{-1}$ and was on average $24 \pm 14 \mathrm{~s}^{-1}$. $\mathrm{OH}$ reactivity had the same trend of temperature and PAR, with a diurnal profile that demonstrates its dependency on the emission and profile of biogenic compounds emitted by the forest, released when sunrise started and temperature increased. During 11 June 2014, OH reactivity started to increase at 6:00 when the sun rose and reached a maximum around 10:30 and again around 16:00, associated with more intense solar radiation. It decreased after sunset, at 20:00 when temperature and light also reduced. Remarkably, the profile of $\mathrm{OH}$ reactivity resembled that of isoprene concentration, except for the morning peak (10:30), which could be possibly associated with the release in the atmosphere of oxygenated molecules. The $\mathrm{OH}$ reactivity sampled at $10 \mathrm{~m}$ had also a diurnal profile. Compared to the $\mathrm{OH}$ reactivity measured at $2 \mathrm{~m}$, here the profile resulted slightly shifted due 
to enhanced ambient temperature during the late afternoon on both sampling days. On 7 June 2014 it started to increase at 06:30, had its maximum around 18:00 and decreased at 21:30. On 8 June 2014 it increased at 06:30 and reached its maximum at $14: 15$.

\subsection{Measured and calculated $\mathrm{OH}$ reactivity}

We compared the total $\mathrm{OH}$ reactivity measured with the CRM instrument with the one calculated from the concentrations of the measured trace gases and their rate coefficients with $\mathrm{OH}$. Table 1 illustrates the classes and species measured by ancillary methods deployed on the field and used to compute their relative contribution to the $\mathrm{OH}$ reactivity. It has to be noted that due to instrument availability and the relative homogeneity of species emitted by the forest, only a few primary emitted compounds and main atmospheric species were measured and used to calculate the $\mathrm{OH}$ reactivity. For methane and carbon monoxide we derived a mean value from measurements run in 2012: 1900 and 180 ppbv, respectively. The $\mathrm{OH}$ reactivity given by the oxidation products of isoprene (ISOP.OXs) was calculated from their measured total concentration and the mean rate coefficient of the reaction of MVK and MACR with $\mathrm{OH}$. Since we did not separate the different ISOP.OXs, we could not determine the exact fraction of MVK and MACR contributing to the $\mathrm{OH}$ reactivity, which leads to a slight overestimation of the calculated reactivity (Rivera-Rios et al., 2014); in our case such overestimation is not significant due to the higher abundance of isoprene.

The calculated $\mathrm{OH}$ reactivity was between 5 and $58 \mathrm{~s}^{-1}$ and on average $24 \pm 19 \mathrm{~s}^{-1}$ between 11 and 12 June 2014 at $2 \mathrm{~m}$ inside the canopy. At $10 \mathrm{~m}$, above the canopy height, it varied between 3 and $55 \mathrm{~s}^{-1}$, being on average $19 \pm 12 \mathrm{~s}^{-1}$.

Figures 5 and 6 show the covariation between measured (black line) and calculated (green line) $\mathrm{OH}$ reactivity during 11-12 June 2014 at $2 \mathrm{~m}$ and during 7-8 June 2014 at $10 \mathrm{~m}$, with associated error bars $(35 \%$ for the measured reactivity and $25 \%$ for the calculated reactivity, $1 \sigma$ ).

For both time series, during daytime, inside and above the canopy height, the measured $\mathrm{OH}$ reactivity agreed very well with the calculated one within the instrumental uncertainties. Since there was not a significant difference between the two values we can conclude that no significant missing reactivity was observed in this specific ecosystem in the Mediterranean basin during our measurement campaign. In addition, the precise characterization of the composition of air even at $10 \mathrm{~m}$ height corroborates the weak oxidation of primary compounds within the canopy (Kalogridis et al., 2014).

Simultaneous ancillary measurements of trace gases permit to resolve the total $\mathrm{OH}$ reactivity into the relative contributions of the individual species. Figures 7 and 8 show the breakdown of reactive components in $\mathrm{OH}$ reactivity during daytime and nighttime at the two heights considered. In all cases the dominant reactive species was isoprene. Isoprene is among the most reactive compounds towards $\mathrm{OH}$, the most abundant compound in this forest and nearly the only compound emitted by downy oak trees, which constitute the majority of tree species accounted for in this ecosystem. Hence, we expected its large contribution to the reactivity. At $2 \mathrm{~m}$, isoprene represented from 28 to $83 \%$ of the total $\mathrm{OH}$ reactivity during nighttime (total mean $6 \mathrm{~s}^{-1}$ ) and daytime (total mean $29 \mathrm{~s}^{-1}$ ), respectively. At $10 \mathrm{~m}$, it constituted from $24 \%$ during nighttime to $74 \%$ during daytime of the total reactivity (total means 6 and $20 \mathrm{~s}^{-1}$, respectively). The impact of isoprene on $\mathrm{OH}$ reactivity between the two heights of sampling differs by only $9 \%$. When we consider that at $2 \mathrm{~m}$ the data of alkanes+alkenes are missing and similar air temperature was measured at the two heights $\left(30^{\circ} \mathrm{C}\right.$ temperature maximum at $2 \mathrm{~m}$ and $32^{\circ} \mathrm{C}$ maximum at $10 \mathrm{~m}$ ), we can conclude that no substantial difference in the atmospheric composition in terms of reactive gases existed between the two heights of sampling. Inside the canopy during daytime, all the measured species apart from isoprene contributed in total about $17 \%$ to the $\mathrm{OH}$ reactivity. Carbon monoxide, $\mathrm{HCHO}$ and $\mathrm{NO}_{2}$ were the second most important species, accounting for $3 \%$ each, followed by acetaldehyde, MVK+MACR and monoterpenes with $2 \%$ each and all the other compounds with less. During nighttime, the concentration of isoprene reduced to a few pptv and other species such as $\mathrm{CO}$ and methane which are more stable in the atmosphere became more important, contributing to 16 and $5 \%$, respectively. Formaldehyde, $\mathrm{NO}_{2}$, acetaldehyde, MVK+MACR and monoterpenes represented, respectively, $11,16,8,5$ and $4 \%$. Above the canopy during daytime the second most reactive species were $\mathrm{CO}, \mathrm{NO}_{2}, \mathrm{HCHO}$ and $\mathrm{MVK}+\mathrm{MACR}(5,5,4$ and 3\%). Above the canopy but during nighttime, $\mathrm{CO}, \mathrm{NO}_{2}, \mathrm{HCHO}$, alkanes+alkenes, $\mathrm{MVK}+\mathrm{MACR}$, methane and acetaldehyde weighted, respectively, 17, 15, 14, 6, 5, 5 and 5\%. Monoterpenes weighted about $2-1 \%$ during daytime and $4 \%$ during the night in both cases. Monoterpenes are also very reactive BVOCs towards $\mathrm{OH}$; when present in the atmosphere they can compete with isoprene in terms of reactivity. At OHP, monoterpenes mixing ratios were low (see Table 3); they did not constitute a major class of compounds in the area and by consequence their contribution to the $\mathrm{OH}$ reactivity was poor.

\subsection{Nighttime missing reactivity}

During the nights between 7 and 8 and between 11 and 12 June 2014, the measured total $\mathrm{OH}$ reactivity and the calculated reactivity reported some discrepancies (Figs. 5 and 6). For the results above the canopy such discrepancy was visible around midnight, and significant differences were observed from 01:00 to 04:30 (Fig. 6). Inside the canopy, the signal of total $\mathrm{OH}$ reactivity started to scatter around 23.30, again at 02:00 and decreased back to the signal of calculated $\mathrm{OH}$ reactivity around 04:30 (Fig. 5). Both differences were 13$14 \mathrm{~s}^{-1}$ and accounted for a fraction higher than $50 \%$ of missing $\mathrm{OH}$ reactivity. Such values of missing reactivity are com- 

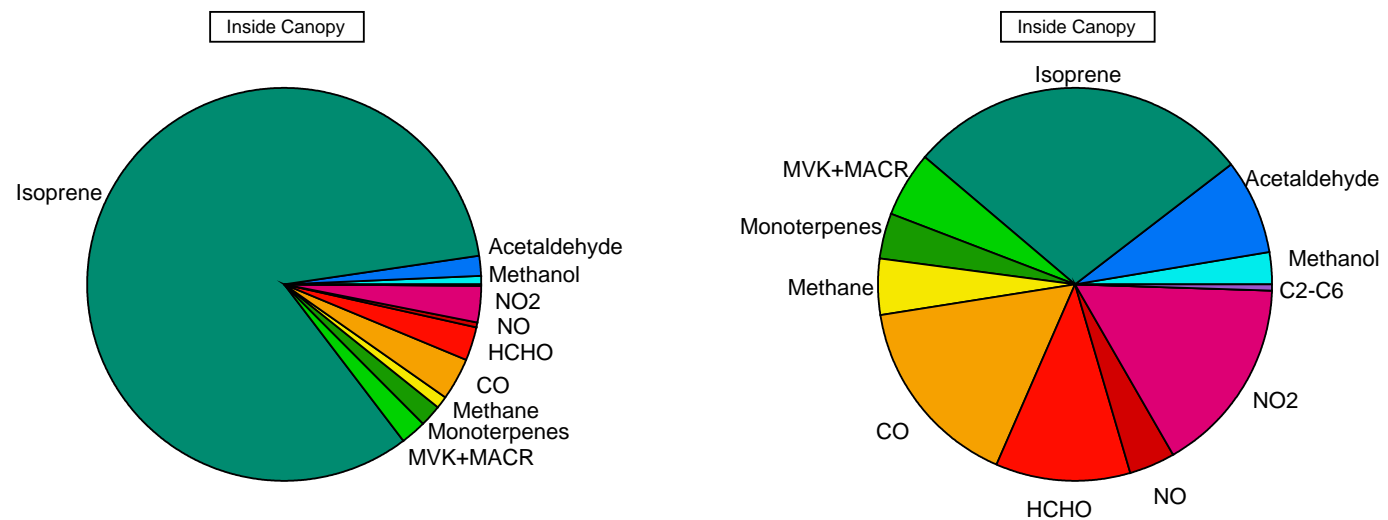

Figure 7. The components of $\mathrm{OH}$ reactivity inside the canopy ( $2 \mathrm{~m}$ height) during daytime (left pie chart) and during nighttime (right pie chart). Data refer to air masses sampled at OHP during 11-12 June 2014. Total OH reactivity was $29 \mathrm{~s}^{-1}$ (daytime mean value) and $6 \mathrm{~s}^{-1}$ (nighttime mean value). All compounds reported in Table 1 were used to calculate their relative contributions. C2-C6 refers to alkanes and alkenes in the fraction C2-C6.
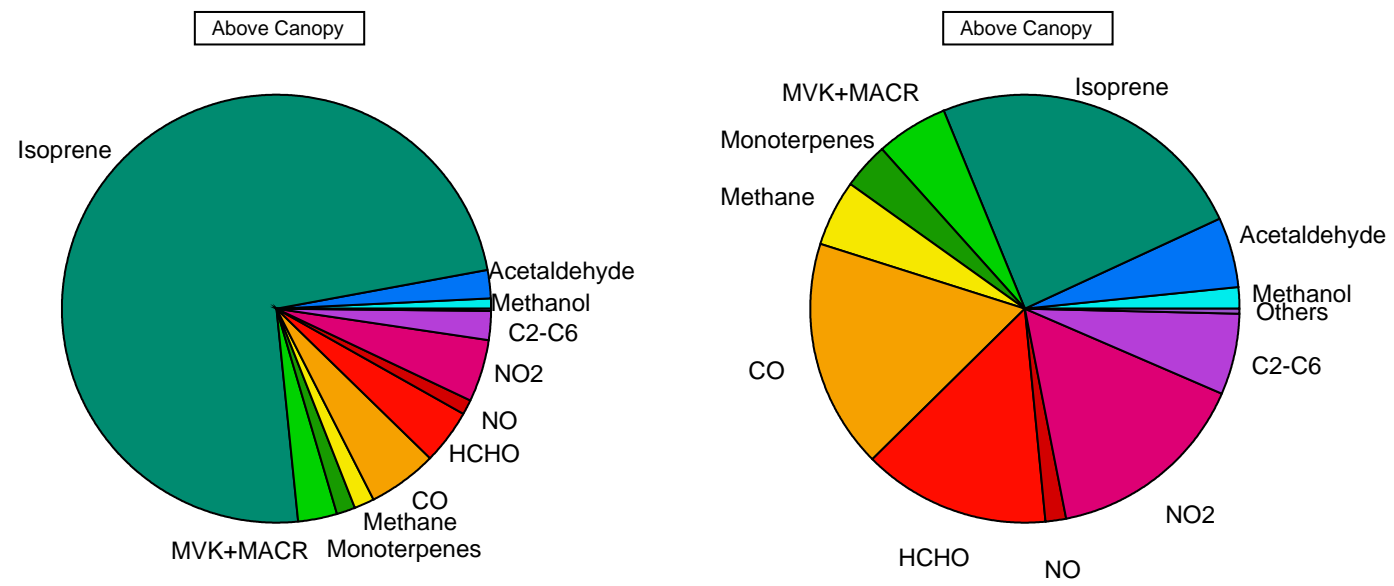

Figure 8. The components of $\mathrm{OH}$ reactivity above the canopy $(10 \mathrm{~m}$ height) during daytime (left pie chart) and during nighttime (right pie chart). Data refer to air masses sampled at OHP during 7-8 June 2014. Total OH reactivity was $20 \mathrm{~s}^{-1}$ (daytime mean value) and $6 \mathrm{~s}^{-1}$ (nighttime mean value). All compounds reported in Table 1 were used to calculate their relative contributions. C2-C6 refers to alkanes and alkenes in the fraction C2-C6. Others refer to the sum of the contributions of: acetonitrile, acetone, MEK, benzene and toluene.

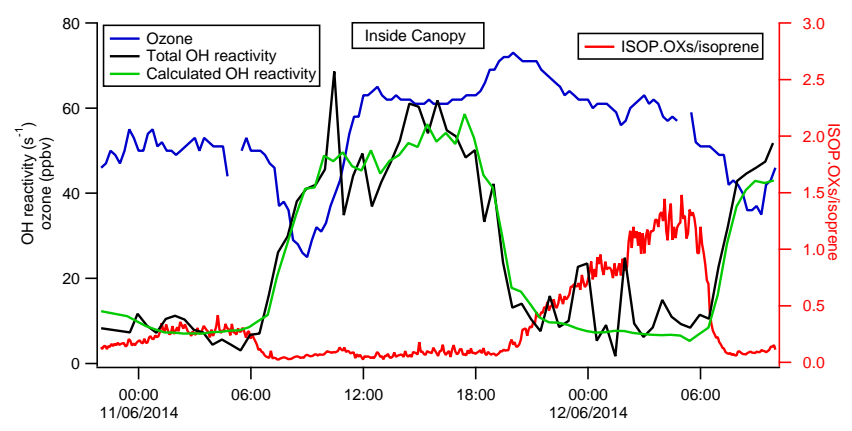

Figure 9. Total $\mathrm{OH}$ reactivity, calculated reactivity and ISOP.OXs/isoprene ratio at $2 \mathrm{~m}$ height. Ozone data were acquired a few hundred meters away from the sampling area. parable to values of total $\mathrm{OH}$ reactivity measured in boreal and temperate forests (Sinha et al., 2010; Ren et al., 2006).

To investigate the molecules responsible for the missing $\mathrm{OH}$ reactivity, we examined the variability of the calculated and measured $\mathrm{OH}$ reactivity, along with primary biogenic compounds, anthropogenic tracers, OVOCs (oxygenated volatile organic compounds) and ozone concentrations, and ISOP.OXs/isoprene ratio. It is striking that whereas isoprenoids exhibited a regular diurnal cycle, all OVOCs showed increased nighttime values (Figs. 3 and 4). Species profiles as reported in Fig. 3 show that on 7 June 2014 ISOP.OXs and HCHO started to increase during the day, around 13:00, reached a maximum around 19:30 and then decreased during the night. While isoprene concentration is flatter much faster due to its higher reaction rate, its oxidation products reacted slower, which explains the higher 


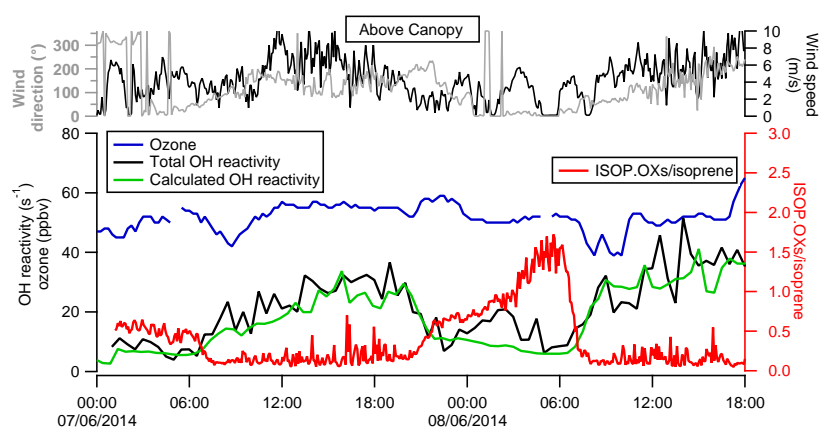

Figure 10. Total $\mathrm{OH}$ reactivity, calculated reactivity and ISOP.OXs/isoprene ratio at $10 \mathrm{~m}$ height. Ozone data were acquired a few hundred meters away from the sampling area. The upper panel shows wind direction and wind speed data.

ISOP.OXs/isoprene ratio observed. Indeed, higher variability was observed on short timescale for isoprene compared to ISOP.OXs ( 0.9 and 0.5 , respectively, relative standard deviation over the mean value during 7 June 2014). The ISOP.OXs/isoprene ratio had the same magnitude and trend for both missing reactivity events and reached a maximum during these two specific nights compared to the rest of the campaign period (Fig. 3). Interestingly, ISOP.OXs/isoprene increases when ozone decreases, especially for measurements at $10 \mathrm{~m}$ (Figs. 9 and 10). Profiles of other measured OVOCs $(m / z 45, m / z 59, m / z 73$; Fig. 4$)$ show higher concentrations around midnight of both nights, suggesting an accumulation of oxygenated compounds and an intense nighttime chemistry. Indeed, meteorological parameters such as wind speed and wind direction for data collected at $10 \mathrm{~m}$ help to show that the wind blew from the same direction with low speed during the night between 7 and 8 June 2014, suggesting more stable meteorological conditions which could have favored nighttime chemistry (Fig. 10). Daytime air temperature on these 2 days was also the highest registered over the whole measurement campaign (Fig. 3). During nighttime, the atmospheric boundary layer is shallower, producing two main effects evident in Figs. 9 and 10: on one hand, it favors ozone deposition on leaves surface, which could be the main reason of the observed decrease of ozone concentration; on the other hand, it concentrates the atmospheric species present in ambient air, resulting in higher concentration of the compounds more stable in the atmosphere.

Several evidences make us believe that the production of OVOCs was linked to the oxidation of biogenic molecules. Firstly, common anthropogenic tracers such as acetonitrile and benzene did not show any particular increase during these events, supporting the idea that such nighttime higher concentrations of oxidized compounds in the atmosphere were associated with local drivers rather than transport. Secondly, we observed an increase in atmospheric levels of some masses measured by the PTR-MS and not used before to calculate the $\mathrm{OH}$ reactivity, such as $m / z 47, m / z 61, m / z 75$,

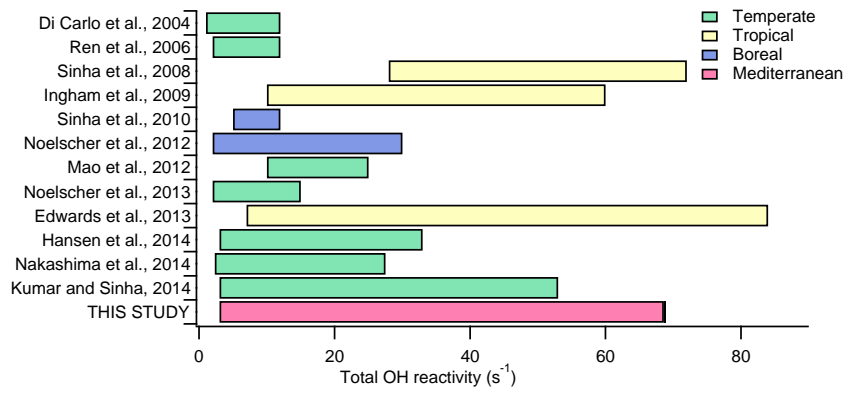

Figure 11. Total $\mathrm{OH}$ reactivity results from all the published experiments conducted worldwide at forested sites. Bars refer to the ranges observed between the minimum (often corresponding to the instrumental LoD) and the maximum values published. Studies were all conducted during spring/summertime. This study and those from Sinha and Noelscher adopted the comparative reactivity method; di Carlo, Ren, Mao, Ingham, Edwards and Hansen used a total $\mathrm{OH}$ loss rate measurement based on laser-induced fluorescence; Nakashima deployed a laser-induced fluorescence pump and probe technique (see references for instrumental details).

$m / z 83, m / z 87$ and $m / z 101$. According to the existing literature, these protonated masses can be identified as oxidation products resulting from the degradation of isoprene and associated, respectively, with formic acid, acetic acid, hydroxyacetone, 3-methylfuran and other unsaturated C5, methacrylic acid and isoprene hydroperoxides (Warneke et al., 2001; Holzinger et al., 2002). We estimated roughly the contribution of such species to the calculated $\mathrm{OH}$ reactivity and found out that only a small fraction of the missing $\mathrm{OH}$ reactivity could be explained. Therefore there must be other unmeasured species that were formed locally, very likely OVOCs that were present during those nights.

Gas phase chemistry during nighttime is usually initiated by ozone and the nitrate radical. The low levels of $\mathrm{NO}_{x}$ observed at the site (nighttime $\mathrm{NO}$ was maximum $0.8 \mathrm{ppbv}$ and on average $0.14 \pm 0.13 \mathrm{ppbv}$ ) indicate that nitrate chemistry is not a probable source of such oxidized compounds; however, ozone isoprene chemistry is slow and cannot alone explain their production in the gas phase (isoprene lifetime with nitrate is $1.6 \mathrm{~h}$ while with ozone is calculated to be 1.3 days; Atkinson and Arey, 2003). If the unmeasured OVOCs were neither generated exclusively from isoprene nor had anthropogenic precursors, we speculate that these unmeasured OVOCs must have been a combination of higher-generation products derived from isoprene oxidation and OVOCs, resulting from reactive primary biogenic precursors, other than isoprene, and more reactive towards ozone. We can expect that these biogenic precursors were larger molecules that could not be measured by our instrumentation.

Holzinger et al. (2005) measured a whole class of oxidation products in a pine forest and suggested that they must have formed from reactions of ozone with very reactive terpene-like compounds. He estimated these compounds 
to be emitted approximately 6-30 times more than the emission of the observed monoterpenes above his forest. Karl et al. (2005) have identified the same oxygenated compounds for different pine species and speculated their production at the leaf level rather than in the gas phase. Recent experiments on leaves of tobacco plants have identified the unsaturated semivolatile compounds undergoing reactions on the leaves surface (Jud et al., 2016). Those compounds once deposited on the leaves quickly undergo surface oxidation reactions with ozone releasing volatile products into the gas phase. Oxidation reactions are favored by higher ambient $\mathrm{RH}$ and high ozone levels, and they can also occur when leaves stomata are closed. Measuring the species initiating these surface reactions is extremely difficult with the instruments we had on the field, and therefore we do not have more clues to support this hypothesis or exclude it has occurred in the forest of OHP. Focused studies on the leaves of downy oak trees with branch enclosure techniques would be of help to elucidate it.

\section{5 $\mathrm{OH}$ reactivity at other biogenic sites}

Our results of reactivity from OHP constitute the first data set of total $\mathrm{OH}$ reactivity measured in a Mediterranean forest. Nevertheless, several observations to study the emissions from different plant species and their evolution due to natural factors such as light and air temperature in other forested sites exist to date. $\mathrm{OH}$ reactivity observations have been of great help over the years to elucidate the presence of unknown compounds and to eventually assess BVOCs oxidation patterns which had not before been characterized (Nakashima et al., 2012; Nölscher et al., 2014). In addition, biogenic species constitute a class of compounds with the highest reactivity towards the hydroxyl radical. OH reactivity during springtime and summertime in forests is usually higher than in metropolitan areas which are often polluted by less reactive hydrocarbons.

Figure 11 illustrates all the existing studies of $\mathrm{OH}$ reactivity conducted in biogenic environments with their corresponding references. Colored bars show the range of reactivity measured at the site, while colors refer to different types of climatic zones to which the studied forests belong. The reader should note that not all the studies were carried out using the same method (see figure caption for more details).

The forest at OHP is among the investigated biogenic sites producing the highest $\mathrm{OH}$ reactivity worldwide. The only two sites where a higher reactivity was reached is the tropical rainforest of Borneo (Edwards et al., 2013), where a maximum of $84 \mathrm{~s}^{-1}$ was reported and the tropical rainforest of Suriname with a maximum of $72 \mathrm{~s}^{-1}$ (Sinha et al., 2008). Tropical forests are usually more heterogeneous in plants species and BVOCs emission patterns compared to the forest at OHP, which is also particularly homogeneous compared to other Mediterranean forests. In Borneo, the dominant primary species to the $\mathrm{OH}$ reactivity was also isoprene (relative contribution of $36.8 \%$ ), but terpenes made up $7 \%$ and the largest portion of reactivity was attributed to the oxidation products of BVOCs and products intermediates $(47.1 \%)$. In conclusion, on one hand the intense temperature and solar radiation result in similar emission strength and reactivity, while on the other hand biodiversity and canopy structure draw the major differences between the two sites. Indeed, the forest at OHP, besides being homogeneous, is shorter and sparser compared to tropical forests; such structure allows a better mixing of the air masses and a faster transport of the primary species to the atmosphere.

By comparison, the investigated mixed temperate forests and boreal forests produced lower $\mathrm{OH}$ reactivity, which can also be attributed to the lower temperature and less intense solar radiation leading to weaker emissions from the local canopies.

\section{Summary and conclusion}

During late spring 2014 at the downy oaks forest of the site Observatoire de Haute Provence we found that the total $\mathrm{OH}$ reactivity was maximum $69 \mathrm{~s}^{-1}$ at $2 \mathrm{~m}$ (inside the canopy) and $68 \mathrm{~s}^{-1}$ at $10 \mathrm{~m}$ (above the canopy). Interestingly, during daytime, the measured $\mathrm{OH}$ reactivity at both heights was in good agreement, within the measurements uncertainties, with the calculated $\mathrm{OH}$ reactivity obtained from the suite of measurements of trace gases concentration available during our field experiment. Hence, we did not observe any missing $\mathrm{OH}$ reactivity either inside or above the forest.

In addition, considering the homogeneity of the forest and strong reactivity of isoprene, we expected isoprene to be the species contributing the most to the $\mathrm{OH}$ reactivity, at least for measurements at $2 \mathrm{~m}$ high. We found indeed that inside the canopy during daytime, isoprene contributed to the $\mathrm{OH}$ reactivity at $83 \%$, followed by $\mathrm{CO}, \mathrm{NO}_{2}$ and $\mathrm{HCHO}$. Above the canopy height, isoprene made up to $74 \%$, followed by $\mathrm{CO}, \mathrm{NO}_{2}, \mathrm{HCHO}$ and MVK+MACR. Such results indicate that there was not a significant difference in the speciation inside and above the canopy. During nighttime, when isoprene emissions stopped and atmospheric concentrations were a few pptv, long-lived species such as $\mathrm{CO}$ and methane contributed to about 16-17 and 5\% for both inside and above the canopy. Still, even by night, isoprene accounted for the largest portion of $\mathrm{OH}$ reactivity.

The low levels of isoprene oxidation products observed during the day indicate that the intracanopy oxidation is low, and almost all the isoprene emitted by the canopy is transported to the atmosphere, which confirms the previous experimental work on isoprene fluxes conducted during spring 2012. The fact that no missing OH reactivity was observed, especially above the canopy, additionally corroborates the fact that no significant unmeasured compound, the product of the oxidation of isoprene, was present.

During the nights between 7-8 and 11-12 June 2014 from sampling above and inside the canopy, respectively, the to- 
tal $\mathrm{OH}$ reactivity we measured was significantly higher compared to the calculated $\mathrm{OH}$ reactivity. Such missing reactivity accounted for more than $50 \%$ and can be explained by locally produced unmeasured oxidation products. We speculate that unmeasured OVOCs represent a mixture of species including higher-generation products resulting from isoprene oxidation and products of the reaction between reactive biogenic precursors and ozone.

Our work represents the first data set to date of total $\mathrm{OH}$ reactivity measured in a Mediterranean forest. In a worldwide perspective, the investigated forest of downy oaks at $\mathrm{OHP}$ produces an $\mathrm{OH}$ reactivity among the highest measured. Remarkably, only tropical forests showed to be as reactive as OHP. Lower $\mathrm{OH}$ reactivity was measured in boreal and mixed temperate forests due to the lower temperature and solar radiation and possibly to the more heterogeneous-like forests (i.e., less abundance of isoprene).

The Mediterranean region is rich in biodiversity, and biogenic activity is enhanced by its characteristic climate. Out of 2 million $\mathrm{km}^{2}$ of surface only about $100000 \mathrm{~km}^{2}$ remains undisturbed by human activity. We expect, therefore, that $\mathrm{OH}$ reactivity in the Mediterranean can vary significantly depending on the type of vegetation and its extension and interaction with pollutants derived by human activity. In addition, the Mediterranean is a hotspot for climate change. This issue will certainly impact the biogenic emission strength and pattern, which will influence the total $\mathrm{OH}$ reactivity. With our work we would like to stimulate interest in studying the $\mathrm{OH}$ reactivity and BVOC levels at diverse biogenic sources in the Mediterranean area for extensive periods.

\section{The Supplement related to this article is available online at doi:10.5194/acp-16-1619-2016-supplement.}

Acknowledgements. This study was supported by European Commission's 7th Framework Programme under grant agreement number 287382 "PIMMS", ANR-CANOPEE and ChArMEx, CEA and CNRS. We would like to thank N. Bonnaire for his work on the GC-MS analysis. We acknowledge J. P. Orts, I. Reiter, the staff at $\mathrm{O}_{3} \mathrm{HP}$ and at Gerard Megie, INERIS, for logistical help. We thank F. Dulac and E. Hamonou for managing the ChArMEx project. We are thankful to Sabina Assan for helping with the English revision of the manuscript and to the two anonymous reviewers for their useful comments and suggestions.

Edited by: J. Rinne

\section{References}

Atkinson, R.: Kinetics and mechanisms of the gas-phase reactions of the hydroxyl radical with organic compounds under atmospheric conditions, Chem. Rev., 86, 69-201, doi:10.1021/cr00071a004, 1986.

Atkinson, R.: Atmospheric chemistry of VOCs and NOx, Atmos. Environ., 34, 2063-2101, doi:10.1016/S1352-2310(99)00460-4, 2000.

Atkinson, R. and Arey, J.: Atmospheric Chemistry of Biogenic Organic Compounds, Acc. Chem. Res., 31, 574-583, doi:10.1021/ar970143z, 1998.

Atkinson, R. and Arey, J.: Gas-phase tropospheric chemistry of biogenic volatile organic compounds: a review, Atmos. Environ., 37, 197-219, doi:10.1016/S1352-2310(03)00391-1, 2003.

Atkinson, R., Aschmann, S. M., Winer, A. M., and Carter, W. P. L.: Rate constants for the gas phase reactions of $\mathrm{OH}$ radicals and O3 with pyrrole at $295 \pm 1 \mathrm{~K}$ and atmospheric pressure, Atmos. Environ., 18, 2105-2107, doi:10.1016/0004-6981(84)90196-3, 1984.

Atkinson, R., Baulch, D. L., Cox, R. A., Jr, R. F. H., Kerr, J. A., Rossi, M. J., and Troe, J.: Evaluated Kinetic and Photochemical Data for Atmospheric Chemistry: Supplement VI. IUPAC Subcommittee on Gas Kinetic Data Evaluation for Atmospheric Chemistry, J. Phys. Chem. Ref. Data, 26, 1329-1499, doi:10.1063/1.556010, 1997.

Baghi, R., Durand, P., Jambert, C., Jarnot, C., Delon, C., Serça, D., Striebig, N., Ferlicoq, M., and Keravec, P.: A new disjunct eddy-covariance system for BVOC flux measurements - validation on $\mathrm{CO}_{2}$ and $\mathrm{H}_{2} \mathrm{O}$ fluxes, Atmos. Meas. Tech., 5, 3119-3132, doi:10.5194/amt-5-3119-2012, 2012.

Bonsang, B., Polle, C., and Lambert, G.: Evidence for marine production of isoprene, Geophys. Res. Lett., 19, 1129-1132, doi:10.1029/92GL00083, 1992.

Carlo, P. D., Brune, W. H., Martinez, M., Harder, H., Lesher, R., Ren, X., Thornberry, T., Carroll, M. A., Young, V., Shepson, P B., Riemer, D., Apel, E., and Campbell, C.: Missing OH Reactivity in a Forest: Evidence for Unknown Reactive Biogenic VOCs, Science, 304, 722-725, doi:10.1126/science.1094392, 2004.

Claeys, M., Graham, B., Vas, G., Wang, W., Vermeylen, R., Pashynska, V., Cafmeyer, J., Guyon, P., Andreae, M. O., Artaxo, P., and Maenhaut, W.: Formation of Secondary Organic Aerosols Through Photooxidation of Isoprene, Science, 303, 1173-1176, doi:10.1126/science.1092805, 2004.

Dasgupta, P. K., Dong, S., Hwang, H., Yang, H.-C., and Genfa, Z.: Continuous liquid-phase fluorometry coupled to a diffusion scrubber for the real-time determination of atmospheric formaldehyde, hydrogen peroxide and sulfur dioxide, Atmos. Environ., 22, 949-963, doi:10.1016/0004-6981(88)902739, 1988

De Gouw, J. and Warneke, C.: Measurements of volatile organic compounds in the earth's atmosphere using proton-transferreaction mass spectrometry, Mass Spectrom. Rev., 26, 223-257, doi:10.1002/mas.20119, 2007.

Dillon, T. J., Tucceri, M. E., Dulitz, K., Horowitz, A., Vereecken, L., and Crowley, J. N.: Reaction of Hydroxyl Radicals with C4H5N (Pyrrole): Temperature and Pressure Dependent Rate Coefficients, J. Phys. Chem. A, 116, 6051-6058, doi:10.1021/jp211241x, 2012.

Edwards, P. M., Evans, M. J., Furneaux, K. L., Hopkins, J., Ingham, T., Jones, C., Lee, J. D., Lewis, A. C., Moller, S. J., Stone, D., Whalley, L. K., and Heard, D. E.: OH reactivity in a South East Asian tropical rainforest during the Oxidant and Particle Pho- 
tochemical Processes (OP3) project, Atmos. Chem. Phys., 13, 9497-9514, doi:10.5194/acp-13-9497-2013, 2013.

Fuentes, J. D., Gu, L., Lerdau, M., Atkinson, R., Baldocchi, D., Bottenheim, J. W., Ciccioli, P., Lamb, B., Geron, C., Guenther, A., Sharkey, T. D., and Stockwell, W.: Biogenic Hydrocarbons in the Atmospheric Boundary Layer: A Review, B. Am. Meteorol. Soc., 81, 1537-1575, doi:10.1175/1520-0477(2000)081< 1537:BHITAB> 2.3.CO;2, 2000.

Genard-Zielinski, A.-C., Boissard, C., Fernandez, C., Kalogridis, C., Lathière, J., Gros, V., Bonnaire, N., and Ormeño, E.: Variability of BVOC emissions from a Mediterranean mixed forest in southern France with a focus on Quercus pubescens, Atmos. Chem. Phys., 15, 431-446, doi:10.5194/acp-15-431-2015, 2015.

Giorgi, F.: Climate change hot-spots, Geophys. Res. Lett., 33, L08707, doi:10.1029/2006GL025734, 2006.

Giorgi, F. and Lionello, P.: Climate change projections for the Mediterranean region, Glob. Planet. Change, 63, 90-104, doi:10.1016/j.gloplacha.2007.09.005, 2008.

Giorgi, F., Im, E.-S., Coppola, E., Diffenbaugh, N. S., Gao, X. J., Mariotti, L., and Shi, Y.: Higher Hydroclimatic Intensity with Global Warming, J. Clim., 24, 5309-5324, doi:10.1175/2011JCLI3979.1, 2011.

Guenther, A., Hewitt, C. N., Erickson, D., Fall, R., Geron, C., Graedel, T., Harley, P., Klinger, L., Lerdau, M., Mckay, W. A., Pierce, T., Scholes, B., Steinbrecher, R., Tallamraju, R., Taylor, J., and Zimmerman, P.: A global model of natural volatile organic compound emissions, J. Geophys. Res.-Atmos., 100, 8873-8892, doi:10.1029/94JD02950, 1995.

Guenther, A., Karl, T., Harley, P., Wiedinmyer, C., Palmer, P. I., and Geron, C.: Estimates of global terrestrial isoprene emissions using MEGAN (Model of Emissions of Gases and Aerosols from Nature), A tmos. Chem. Phys., 6, 3181-3210, doi:10.5194/acp6-3181-2006, 2006.

Hansen, R. F., Griffith, S. M., Dusanter, S., Rickly, P. S., Stevens, P. S., Bertman, S. B., Carroll, M. A., Erickson, M. H., Flynn, J. H., Grossberg, N., Jobson, B. T., Lefer, B. L., and Wallace, H. W.: Measurements of total hydroxyl radical reactivity during CABINEX 2009 - Part 1: field measurements, Atmos. Chem. Phys., 14, 2923-2937, doi:10.5194/acp-14-2923-2014, 2014.

Hirsch, A. I., Munger, J. W., Jacob, D. J., Horowitz, L. W., and Goldstein, A. H.: Seasonal variation of the ozone production efficiency per unit NOx at Harvard Forest, Massachusetts, J. Geophys. Res.-Atmos., 101, 12659-12666, doi:10.1029/96JD00557, 1996.

Holzinger, R., Sanhueza, E., von Kuhlmann, R., Kleiss, B., Donoso, L., and Crutzen, P. J.: Diurnal cycles and seasonal variation of isoprene and its oxidation products in the tropical savanna atmosphere, Global Biogeochem. Cy., 16, 1074, doi:10.1029/2001GB001421, 2002.

Holzinger, R., Lee, A., Paw, K. T., and Goldstein, U. A. H.: Observations of oxidation products above a forest imply biogenic emissions of very reactive compounds, Atmos. Chem. Phys., 5, 67-75, doi:10.5194/acp-5-67-2005, 2005.

Ingham, T., Goddard, A., Whalley, L. K., Furneaux, K. L., Edwards, P. M., Seal, C. P., Self, D. E., Johnson, G. P., Read, K. A., Lee, J. D., and Heard, D. E.: A flow-tube based laser-induced fluorescence instrument to measure $\mathrm{OH}$ reactivity in the troposphere, Atmos. Meas. Tech., 2, 465-477, doi:10.5194/amt-2-465-2009, 2009.
Jacob, D. J., Field, B. D., Jin, E. M., Bey, I., Li, Q., Logan, J. A., Yantosca, R. M., and Singh, H. B.: Atmospheric budget of acetone, J. Geophys. Res.-Atmos., 107, 5-1, doi:10.1029/2001JD000694, 2002.

Jacob, D. J., Field, B. D., Li, Q., Blake, D. R., de Gouw, J., Warneke, C., Hansel, A., Wisthaler, A., Singh, H. B., and Guenther, A.: Global budget of methanol: Constraints from atmospheric observations, J. Geophys. Res.-Atmos., 110, D08303, doi:10.1029/2004JD005172, 2005.

Jenkin, M. E., Boyd, A. A., and Lesclaux, R.: Peroxy Radical Kinetics Resulting from the $\mathrm{OH}$-Initiated Oxidation of 1,3-Butadiene, 2,3-Dimethyl-1,3-Butadiene and Isoprene, J. Atmos, Chem., 29, 267-298, doi:10.1023/A:1005940332441, 1998.

Jud, W., Fischer, L., Canaval, E., Wohlfahrt, G., Tissier, A., and Hansel, A.: Plant surface reactions: an opportunistic ozone defence mechanism impacting atmospheric chemistry, Atmos. Chem. Phys., 16, 277-292, doi:10.5194/acp-16-277-2016, 2016.

Kalogridis, C., Gros, V., Sarda-Esteve, R., Langford, B., Loubet, B., Bonsang, B., Bonnaire, N., Nemitz, E., Genard, A.-C., Boissard, C., Fernandez, C., Ormeño, E., Baisnêe, D., Reiter, I., and Lathière, J.: Concentrations and fluxes of isoprene and oxygenated VOCs at a French Mediterranean oak forest, Atmos. Chem. Phys., 14, 10085-10102, doi:10.5194/acp-14-10085-2014, 2014.

Karl, T., Harley, P., Guenther, A., Rasmussen, R., Baker, B., Jardine, K., and Nemitz, E.: The bi-directional exchange of oxygenated VOCs between a loblolly pine (Pinus taeda) plantation and the atmosphere, Atmos. Chem. Phys., 5, 3015-3031, doi:10.5194/acp5-3015-2005, 2005.

Karl, T., Guenther, A., Yokelson, R. J., Greenberg, J., Potosnak, M., Blake, D. R., and Artaxo, P.: The tropical forest and fire emissions experiment: Emission, chemistry, and transport of biogenic volatile organic compounds in the lower atmosphere over Amazonia, J. Geophys. Res.-Atmos., 112, D18302, doi:10.1029/2007JD008539, 2007.

Kesselmeier, J. and Staudt, M.: Biogenic Volatile Organic Compounds (VOC): An Overview on Emission, Physiology and Ecology, J. Atmospheric Chem., 33, 23-88, doi:10.1023/A:1006127516791, 1999.

Kesselmeier, J., Bode, K., Schäfer, L., Schebeske, G., Wolf, A., Brancaleoni, E., Cecinato, A., Ciccioli, P., Frattoni, M., Dutaur, L., Fugit, J. L., Simon, V., and Torres, L.: Simultaneous field measurements of terpene and isoprene emissions from two dominant mediterranean oak species in relation to a North American species, Atmos. Environ., 32, 1947-1953, doi:10.1016/S13522310(97)00500-1, 1998.

Kumar V. and Sinha V.: VOC-OHM: A new technique for rapid measurements of ambient total $\mathrm{OH}$ reactivity and volatile organic compounds using a single proton transfer reaction mass spectrometer, Int. J. Mass Spectrom., 374, 55-63, doi:10.1016/j.ijms.2014.10.012, 2014.

Laothawornkitkul, J., Taylor, J. E., Paul, N. D., and Hewitt, C. N.: Biogenic volatile organic compounds in the Earth system, New Phytol., 183, 27-51, doi:10.1111/j.1469-8137.2009.02859.x, 2009.

Lindinger, W. and Jordan, A.: Proton-transfer-reaction mass spectrometry (PTR-MS): on-line monitoring of volatile organic compounds at pptv levels, Chem. Soc. Rev., 27, 347-375, doi:10.1039/A827347Z, 1998. 
Liu, Y. J., Herdlinger-Blatt, I., McKinney, K. A., and Martin, S. T.: Production of methyl vinyl ketone and methacrolein via the hydroperoxyl pathway of isoprene oxidation, Atmos. Chem. Phys., 13, 5715-5730, doi:10.5194/acp-13-5715-2013, 2013.

Mao, J., Ren, X., Zhang, L., Van Duin, D. M., Cohen, R. C., Park, J.-H., Goldstein, A. H., Paulot, F., Beaver, M. R., Crounse, J. D., Wennberg, P. O., DiGangi, J. P., Henry, S. B., Keutsch, F. N., Park, C., Schade, G. W., Wolfe, G. M., Thornton, J. A., and Brune, W. H.: Insights into hydroxyl measurements and atmospheric oxidation in a California forest, Atmos. Chem. Phys., 12, 8009-8020, doi:10.5194/acp-12-8009-2012, 2012.

Mellouki, A. and Ravishankara, A. R.: Regional Climate Variability and its Impacts in the Mediterranean Area, Springer Science \& Business Media., 2007.

Millet, D. B., Guenther, A., Siegel, D. A., Nelson, N. B., Singh, H. B., de Gouw, J. A., Warneke, C., Williams, J., Eerdekens, G., Sinha, V., Karl, T., Flocke, F., Apel, E., Riemer, D. D., Palmer, P. I., and Barkley, M.: Global atmospheric budget of acetaldehyde: 3-D model analysis and constraints from in-situ and satellite observations, Atmos. Chem. Phys., 10, 3405-3425, doi:10.5194/acp-10-3405-2010, 2010.

Mogensen, D., Smolander, S., Sogachev, A., Zhou, L., Sinha, V., Guenther, A., Williams, J., Nieminen, T., Kajos, M. K., Rinne, J., Kulmala, M., and Boy, M.: Modelling atmospheric OH-reactivity in a boreal forest ecosystem, Atmos. Chem. Phys., 11, 97099719, doi:10.5194/acp-11-9709-2011, 2011.

Nakashima, Y., Tsurumaru, H., Imamura, T., Bejan, I., Wenger, J. C., and Kajii, Y.: Total $\mathrm{OH}$ reactivity measurements in laboratory studies of the photooxidation of isoprene, Atmos. Environ., 62, 243-247, doi:10.1016/j.atmosenv.2012.08.033, 2012.

Nakashima, Y., Kato, S., Greenberg, J., Harley, P., Karl, T., Turnipseed, A., Apel, E., Guenther, A., Smith, J., and Kajii, Y.: Total $\mathrm{OH}$ reactivity measurements in ambient air in a southern Rocky mountain ponderosa pine forest during BEACHON-SRM08 summer campaign, Atmos. Environ., 85, 18, doi:10.1016/j.atmosenv.2013.11.042, 2014.

Nölscher, A. C., Williams, J., Sinha, V., Custer, T., Song, W., Johnson, A. M., Axinte, R., Bozem, H., Fischer, H., Pouvesle, N., Phillips, G., Crowley, J. N., Rantala, P., Rinne, J., Kulmala, M., Gonzales, D., Valverde-Canossa, J., Vogel, A., Hoffmann, T., Ouwersloot, H. G., Vilà-Guerau de Arellano, J., and Lelieveld, J.: Summertime total $\mathrm{OH}$ reactivity measurements from boreal forest during HUMPPA-COPEC 2010, Atmos. Chem. Phys., 12, 8257-8270, doi:10.5194/acp-12-8257-2012, 2012a.

Nölscher, A. C., Sinha, V., Bockisch, S., Klüpfel, T., and Williams, J.: Total OH reactivity measurements using a new fast Gas Chromatographic Photo-Ionization Detector (GC-PID), Atmos. Meas. Tech., 5, 2981-2992, doi:10.5194/amt-5-2981-2012, 2012b.

Nölscher, A.C., Bourtsoukidis, E., Bonn, B., Kesselmeier, J., Lelieveld, J., and Williams, J.: Seasonal measurements of total $\mathrm{OH}$ reactivity emission rates from Norway spruce in 2011, Biogeosciences, 10, 4241-4257, doi:10.5194/bg-10-4241-2013, 2013.

Nölscher, A. C., Butler, T., Auld, J., Veres, P., Muñoz, A., Taraborrelli, D., Vereecken, L., Lelieveld, J., and Williams, J.: Using total $\mathrm{OH}$ reactivity to assess isoprene photooxidation via measurement and model, Atmos. Environ., 89, 453-463, doi:10.1016/j.atmosenv.2014.02.024, 2014.
Preunkert, S. and Legrand, M.: Towards a quasi-complete reconstruction of past atmospheric aerosol load and composition (organic and inorganic) over Europe since 1920 inferred from Alpine ice cores, Clim. Past, 9, 1403-1416, doi:10.5194/cp-91403-2013, 2013.

Preunkert, S., Legrand, M., Frey, M. M., Kukui, A., Savarino, J., Gallée, H., King, M., Jourdain, B., Vicars, W., and Helmig, D.: Formaldehyde (HCHO) in air, snow, and interstitial air at Concordia (East Antarctic Plateau) in summer, Atmos. Chem. Phys., 15, 6689-6705, doi:10.5194/acp-15-6689-2015, 2015.

Rainer Steinbrecher, G. S.: Intra- and inter-annual variability of VOC emissions from natural and semi-natural vegetation in $\mathrm{Eu}-$ rope and neighbouring countries, Atmos. Environ., 7, 13801391, doi:10.1016/j.atmosenv.2008.09.072, 2009.

Ren, X.: HOx concentrations and $\mathrm{OH}$ reactivity observations in New York City during PMTACS-NY2001, Atmos. Environ., 37, 3627-3637, doi:10.1016/S1352-2310(03)00460-6, 2003.

Ren, X., Brune, W. H., Oliger, A., Metcalf, A. R., Simpas, J. B., Shirley, T., Schwab, J. J., Bai, C., Roychowdhury, U., Li, Y., Cai, C., Demerjian, K. L., He, Y., Zhou, X., Gao, H., and Hou, J.: $\mathrm{OH}, \mathrm{HO}_{2}$, and $\mathrm{OH}$ reactivity during the PMTACSNY Whiteface Mountain 2002 campaign: Observations and model comparison, J. Geophys. Res.-Atmos., 111, D10S03, doi:10.1029/2005JD006126, 2006.

Rinne, H. J. I., Guenther, A. B., Greenberg, J. P., and Harley, P. C.: Isoprene and monoterpene fluxes measured above Amazonian rainforest and their dependence on light and temperature, Atmos. Environ., 36, 2421-2426, doi:10.1016/S1352-2310(01)00523-4, 2002.

Rivera-Rios, J. C., Nguyen, T. B., Crounse, J. D., Jud, W., St. Clair, J. M., Mikoviny, T., Gilman, J. B., Lerner, B. M., Kaiser, J. B., de Gouw, J., Wisthaler, A., Hansel, A., Wennberg, P. O., Seinfeld, J. H., and Keutsch, F. N.: Conversion of hydroperoxides to carbonyls in field and laboratory instrumentation: Observational bias in diagnosing pristine versus anthropogenically controlled atmospheric chemistry, Geophys. Res. Lett., 41, GL061919, doi:10.1002/2014GL061919, 2014.

Schade, G. W. and Goldstein, A. H.: Fluxes of oxygenated volatile organic compounds from a ponderosa pine plantation, J. Geophys. Res.-Atmos., 106, 3111-3123, doi:10.1029/2000JD900592, 2001.

Sindelarova, K., Granier, C., Bouarar, I., Guenther, A., Tilmes, S., Stavrakou, T., Müller, J.-F., Kuhn, U., Stefani, P., and Knorr, W.: Global data set of biogenic VOC emissions calculated by the MEGAN model over the last 30 years, Atmos. Chem. Phys., 14, 9317-9341, doi:10.5194/acp-14-9317-2014, 2014.

Sinha, V., Williams, J., Crowley, J. N., and Lelieveld, J.: The Comparative Reactivity Method - a new tool to measure total $\mathrm{OH}$ Reactivity in ambient air, Atmos. Chem. Phys., 8, 2213-2227, doi:10.5194/acp-8-2213-2008, 2008.

Sinha, V., Williams, J., Lelieveld, J., Ruuskanen, T. M., Kajos, M. K., Patokoski, J., Hellen, H., Hakola, H., Mogensen, D., Boy, M., Rinne, J., and Kulmala, M.: OH Reactivity Measurements within a Boreal Forest: Evidence for Unknown Reactive Emissions, Environ. Sci. Technol., 44, 6614-6620, doi:10.1021/es101780b, 2010.

Steiner, A. H. and Goldstein, A. L.: Biogenic VOCs, in Volatile Organic Compounds in the Atmosphere, edited by: Koppmann, R., 82-128, Blackwell Publishing Ltd, available 
at: http://onlinelibrary.wiley.com/doi/10.1002/9780470988657. ch3/summary (last access: 21 January 2015), 2007.

Tsigaridis, K. and Kanakidou, M.: Importance of volatile organic compounds photochemistry over a forested area in central Greece, Atmos. Environ., 36, 3137-3146, doi:10.1016/S13522310(02)00234-0, 2002.

Warneke, C., Holzinger, R., Hansel, A., Jordan, A., Lindinger, W., Pöschl, U., Williams, J., Hoor, P., Fischer, H., Crutzen, P. J., Scheeren, H. A., and Lelieveld, J.: Isoprene and Its Oxidation Products Methyl Vinyl Ketone, Methacrolein, and Isoprene Related Peroxides Measured Online over the Tropical Rain Forest of Surinam in March 1998, J. Atmos. Chem., 38, 167-185, doi:10.1023/A:1006326802432, 2001.

Whalley, L., Stone, D., and Heard, D.: New insights into the tropospheric oxidation of isoprene: combining field measurements, laboratory studies, chemical modelling and quantum theory, Top. Curr. Chem., 339, 55-95, 2014.

Wiedinmyer, C., Guenther, A., Harley, P., Hewitt, N., Geron, C., Artaxo, P., Steinbrecher, R., and Rasmussen, R.: Global organic emissions from vegetation, Emiss. Atmospheric Trace Compd., Adv. Glob. Change Res., 115-170, 2004.
Williams, J., Holzinger, R., Gros, V., Xu, X., Atlas, E., and Wallace, D. W. R.: Measurements of organic species in air and seawater from the tropical Atlantic, Geophys. Res. Lett., 31, L23S06, doi:10.1029/2004GL020012, 2004.

Yáñez-Serrano, A. M., Nölscher, A. C., Williams, J., Wolff, S., Alves, E., Martins, G. A., Bourtsoukidis, E., Brito, J., Jardine, K., Artaxo, P., and Kesselmeier, J.: Diel and seasonal changes of biogenic volatile organic compounds within and above an Amazonian rainforest, Atmos. Chem. Phys., 15, 3359-3378, doi:10.5194/acp-15-3359-2015, 2015.

Yoshino, A., Sadanaga, Y., Watanabe, K., Kato, S., Miyakawa, Y., Matsumoto, J., and Kajii, Y.: Measurement of total OH reactivity by laser-induced pump and probe technique - comprehensive observations in the urban atmosphere of Tokyo, Atmos. Environ., 40, 7869-7881, doi:10.1016/j.atmosenv.2006.07.023, 2006.

Zannoni, N., Dusanter, S., Gros, V., Sarda Esteve, R., Michoud, V., Sinha, V., Locoge, N., and Bonsang, B.: Intercomparison of two comparative reactivity method instruments inf the Mediterranean basin during summer 2013, Atmos. Meas. Tech., 8, 3851-3865, doi:10.5194/amt-8-3851-2015, 2015. 